Spring 2008

\title{
The Solitude of Latin America: The Struggle for Rights South of the Border
}

Ángel Oquendo

University of Connecticut School of Law

Follow this and additional works at: https://opencommons.uconn.edu/law_papers

Part of the Comparative and Foreign Law Commons, Rule of Law Commons, and the Transnational Law Commons

\section{Recommended Citation}

Oquendo, Ángel, "The Solitude of Latin America: The Struggle for Rights South of the Border" (2008). Faculty Articles and Papers. 216.

https://opencommons.uconn.edu/law_papers/216 


\section{HEINONLINE}

Citation: 43 Tex. Int'I L. J. 185 2007-2008

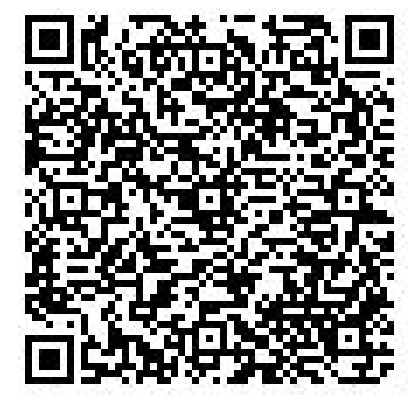

Content downloaded/printed from

HeinOnline (http://heinonline.org)

Mon Aug 15 17:14:00 2016

-- Your use of this HeinOnline PDF indicates your acceptance of HeinOnline's Terms and Conditions of the license agreement available at http://heinonline.org/HOL/License

-- The search text of this PDF is generated from uncorrected OCR text.

-- To obtain permission to use this article beyond the scope of your HeinOnline license, please use:

https://www.copyright.com/ccc/basicSearch.do?

\&operation $=$ go\&search $\mathrm{Type}=0$

\&lastSearch $=$ simple\&all=on\&titleOrStdNo=0163-7479 


\title{
The Solitude of Latin America: The Struggle for Rights South of the Border
}

\author{
ÁNGEL R. OQUENDO*
}

Una nueva y arrasadora utopia de la vida, donde nadie pueda decidir por otros hasta la forma de morir, donde de veras sea cierto el amor y sea posible la felicidad, y donde las estirpes condenadas a cien años de soledad tengan por fin y para siempre una segunda oportunidad sobre la tierra. ${ }^{1}$

\section{SUMMARY}

I. FIRST THINGS FIRST: OVERTURE AND OVERVIEW 186

II. "WHAT'S IN A NAME?": A FAMILY OF RightS REgIMES

III. INTER-GENERATIONAL GUARANTIES: THIN AND THICK 191

IV. PRocedural Claims: Beauty AND THE BeAst 206

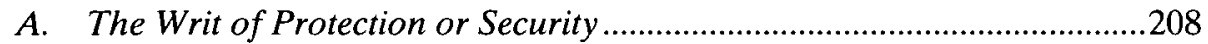

B. Unconstitutionality Actions .................................................................217

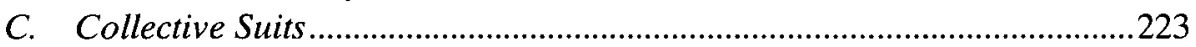

V. IntERnational GUARANTIES: LoCAl AND Global ACTION....................229

VI. Dysfunctions in the Rights Culture: A Walk on the Wild Side ...234

VII. CODA AND FLASHBACK 240

* Olimpiad S. Ioffe Professor of International and Comparative Law, University of Connecticut. Ph.D., M.A. (Philosophy), A.B. (Economics and Philosophy), Harvard University; J.D., Yale Law School The author would like to thank Bethany Berger, Laura Dickinson, Julianne Lombardo, Joseph Page, and Jeremy Paul, as well as participants in workshops held at the law schools of the University of Wisconsin, Washington University, Harvard University, the University of California at Berkeley, Yale University, Georgetown University, the Free University of Berlin, the Getúlio Vargas Foundation in São Paulo, the Inter-American University of Puerto Rico, and the University of the Andes in Bogotá, for their extremely helpful comments on earlier drafts.

1. Gabriel García Márquez, La soledad de América Latina (1982). "A new and sweeping utopia of life, where no one will be able to decide for others how they die, where love will prove true and happiness be possible, and where the races condemned to one hundred years of solitude will have, at last and forever, a second opportunity on earth." Gabriel García Márquez, Nobel Lecture: The Solitude of Latin America, (Dec. 8, 1982) available at http://nobelprize.org/literature/laureates/1982/marquez-lecture.html. (Foreign language sources translated by author unless otherwise noted.) 


\section{First Things First: OVERTURE AND OVERVIEW}

Lo que cuenta, lo que yo he tratado de contar, es el signo afirmativo frente a la escalada del desprecio y del espanto, y esa afirmación tiene que ser lo más solar, lo más vital del hombre: su sed erótica y lúdica, su liberación de los tabúes, su reclamo de una dignidad compartida en una tierra ya libre de este horizonte diario de colmillos y de dólares. ${ }^{2}$

Imagine someone comparing Latin American legal systems in the following terms: "In México, everything is permitted, except what is explicitly prohibited. In Chile, everything is prohibited, except what is explicitly permitted. In Cuba, everything is prohibited, including what is officially permitted. And in Brazil, everything is permitted, especially what is strictly forbidden."

Quick comparisons in law usually take such form. They are crisp, they are humorous, and they are wrong. Deliberate comparisons, in contrast, tend to be complicated, ponderous, and tentative. They rarely deliver a punch line.

While hopefully not entirely devoid of entertainment value, the comparative reflections in this piece are admittedly of the second variety. Accordingly, the underlying argument does not ride on, but rather debunks easy, occasionally amusing, and deeply ingrained stereotypes about Latin America as a land of chaos, lawlessness, oppression, and hopelessness. The article focuses on the remarkable developments of late in the programmatic adjudication, procedural enforcement, and internationalization of fundamental entitlements throughout the region. These accomplishments have periodically taken place even against an adverse backdrop of weak adherence to notions of democracy, individual liberty, legality, and solidarity.

This project examines the way in which law operates across the continent and uncovers core commonalities in the various rights praxes, without losing sight of the significant differences. In the end, a coherent whole manifests itself, with the similarities clearly outweighing the discontinuities. A familial resemblance-though not an overall essence-runs through the multifarious instances. A non-rigid, fluid conception of entitlements, which reveals itself through the achievements alluded to, overarches the region in its full extension, from Tijuana to Tierra del Fuego.

Insofar as the jurisdictions under examination in this paper converge around such an interpretation, they meet a central requirement for the constitution of a congruous legal tradition. In modern and even postmodern times, such a traditional unit would hardly be conceivable if the comprised juridical systems did not have, at least to some degree, a common understanding of what comprises a right. Normally, there must be additional points of overlap in matters such as the model of adjudication, the relevance of scholarly commentary, or the relationship between law and morality. This article does not thoroughly delve into these issues; it simply paves the road to further thought and research on them.

The present work does not merely report on plainly observable correlations, let alone on the corresponding disconnections. Instead, it painstakingly teases a number of positive trends out of real-life cases and thereupon envisages a Latin

2. Julio Cortázar, Presentación, in El LiBro de MANuel (1973) ("What it relates-what I have tried to narrate - is the story of an affirmative gesture against the constant escalation of disdain and horror. Such an affirmation expresses the most basic and vital part of man: his erotic and playful thirst, his liberation from taboos, and his demand for collective dignity in a land free at last from that daily horizon of fangs and dollars."). 
American narrative on legal entitlements. The end result is neither a snapshot of legal reality today nor a pipe dream about the direction that the law should take. Rather, it is an assessment of the full potential of the rights culture presently in place and a somewhat paradoxical evocation of a distant but plausible utopia. ${ }^{3}$ The story therefore unfolds more normatively than descriptively; yet it essentially positions itself somewhere between these two extremes. ${ }^{4}$

The developments at stake have emerged, for the most part, relatively recently and have varied immensely in the extent of their pervasiveness. They include, principally, the vigorous judicial enforcement of negative and (especially) positive guaranties, the establishment of extraordinary procedural safeguards for individual and collective entitlements, and the effective implementation of international human rights. While these achievements do not even remotely constitute the standard modus operandi, they do signal an imaginable future.

This article obviously does not harbor wild ambitions to reconstruct the Latin American rights regime in its entirety, from the bottom up. It solely purports to adumbrate an immanent (though certainly not imminent) alternative framework by highlighting a few crucial current movements. Fleshing out the details will unavoidably entail further investigation. At the moment, one can at most envision the cathedral from afar.

The scope of application of this methodological approach obviously transcends Latin America. This project adopts other theoretical postures that should equally resonate outside Latin Americanist and comparativist circles. It ultimately takes a panoramic perspective and proposes conceptualizing legal entitlements anew, along comprehensive, integral, or organic lines, rather than in the usual narrow and compartmentalized fashion. It calls for exhaustive consideration of positive, procedural, and international rights, in conjunction with their negative, substantive,

3. The method deployed in this piece recalls what Georg W.F. Hegel refers to as "fathoming what is reasonable." GEORG W.F. HEGEL, Vorrede, GRUNDLINIEN DER PHILOSOPHIE DES RECHTS (WERKE VII) 24 (Suhrkamp Verlag 1969) (emphasis in original). "To consider something reasonably," Hegel elucidates, "does not mean to project reason onto it from the outside and thus work it over, but rather to see it as reasonable in itself." Id. $\$ 31$ (Anmerkung). Hegel sets out to discover "the reasonable (das Vernünftige)" within the existing practices and beliefs. Id. at 25,26 . He refers to the reasonable as "the idea," "the immanent substance," or "the present eternal" and contrasts it with the "appearance (Schein) of what is timely and transient," with "external existence," $i d$. at 25 , or "rotten existence," with the "empirical singularity," GeORG W.F. HEGEL, PHÄNOMENOLOGIE DES GEISTES (WERKE III) 52-53 (Suhrkamp Verlag 1969), as well as with "contingency" and "insignificance," GEORG W.F. HEGEL, ENZYKLOPÄDIE DER PHILOSOPHISCHEN WISSENSCHAFTEN III (WERKE X) § 549 (Anmerkung) (Suhrkamp Verlag 1969). It corresponds to "actuality (Wirklichkeit) as posited by the concept," which Hegel sets off against "transient existence (Dasein), external contingency, opinion, appearance without essence, untruth, deception, etc." Georg W.F. Hegel, Grundlinien der Philosophie des Rechts (WeRKE VII), supra, $\S 1$ (Anmerkung). While acknowledging flaws and shunning idealization, philosophers who assume this standpoint ferret out sensible and historically evolved features. Accordingly, Hegel both recognizes the presence of "rotten existence" and insists that the reasonable that he posits "is not merely an ideal." Nonetheless, he conceives a viable and wholesome legal universe and puts it forth as the "inner pulse ... beating within the external forms." Id. at 25 .

4. Similarly, Michael O. Hardimon portrays Hegel's philosophical venture as both normative and descriptive. "The Philosophy of Right is, among other things, an account of the underlying ideals and normative aspirations of the modern social world. ... But, of course, Hegel's approach is not purely normative. He maintains that the norms that the Philosophy of Right articulates are rooted in the existing structures of the modern social world and substantially realized." MICHAEL O. HARDIMON, HEGEL'S Social Philosophy: The Project of Reconciliation 74 (1994). 
and domestic counterparts. The core contention is that deliberation on the latter subset, decoupled from the former, breeds distortion and confusion. Furthermore, this wide-ranging effort involves contemplating the malfunctions and dysfunctionsalong with the functions-of law. Legal theorists and practitioners must, accordingly, pay attention to the interstices or gaps, as well as to the rights realm itself. By the same token, they must carefully determine the prevalence of law failure (non-droit).

Beyond these conceptual insights, the juridical accomplishments under analysis should likewise find far-reaching appeal. They represent more than curious phenomena for the diversion of a casual legal anthropologist. By studying these successes, in addition to other aspects of Latin American law, lawyers in the United States and elsewhere will enhance their capacity to reflect upon and comprehend the reality at home. With law, as with language, people are better able to master their own when they confront and contrast it with that of others. ${ }^{5}$ Almost ineluctably, they become more critical $v i s-\grave{a}$-vis their native institutions and begin visualizing possible transformations on the basis of the experience abroad or as a result of completely new ideas generated through the reflective exercise.

After some obligatory nomenclatural clarifications in Part II, the discussion concentrates in Part III on first-, second-, and third-generation entitlements and applauds the manner in which many Latin American courts have uncompromisingly enforced programmatic guaranties in the last decade or so. Part IV analyzes various widely available procedures for the vindication of rights, including the writ of protection or security (recurso de amparo, mandado de segurança), unconstitutionality actions, and collective suits. It argues, generally, that a concrete understanding of substantive rights requires a basic appreciation of their procedural dimension and, specifically, that the legal systems in question have most conspicuously converged and progressed in the processes through which they implement such claims.

Thereafter, Part V considers international guaranties. The interaction between domestic and transnational rights has become extremely intense in Latin America, as well as almost everywhere else. The study of the former kind of entitlements must therefore take the latter into account. In particular, virtually all countries in this vast territory have signed the American Convention on Human Rights and have accepted the compulsory jurisdiction of the Inter-American Court. The treaty is steadily turning into the functional equivalent of a constitution for all of Latin America. ${ }^{6}$ The individual provisions, along with their official construal, invariably operate not just as international law, but additionally as a paramount component of the national legal orders.

5. See Miguel de Unamuno y Jugo, Comunidad de la lengua hispánica, in LA RAZA VASCA Y EL VASCUENCE; EN TORNO A LA LENGUA ESPAÑOLA 165, 172 (1974) ("For the study and knowledge of other languages advances the study and the improvement of our own."); JOHANN WOLFGANG VON GOETHE, KUNST UND LITERATUR, 12 WERKE 1015 (Hamburger Ausgabe 1998) ("He who knows no foreign languages understands nothing about his own.").

6. The Inter-American Court, for its part, is gradually becoming, somewhat like its European analogue, a constitutional tribunal for the entire continent. It has taken on an increasingly assertive, as well as progressive, role and has impressively grown in prestige over the last two decades. The InterAmerican Commission has decisively contributed to this vital process of consolidation and harmonization of the regional construction of fundamental entitlements. See infra Part V. 
Latin America has made extraordinary headway on all of these fronts precisely as it has tried to tackle specific problems related to the recognition of rights. First, it has often rendered social-welfare entitlements constitutionally enforceable in response to the political and administrative authorities' flagrant disregard of the people's basic needs. Second, the special procedures under assessment have emerged, in great part, to compensate for the shortcomings of ordinary process. Third, international guaranties have attained prominence mostly due to the crass inefficacy of domestic entitlements in the face of unspeakable outrages against human dignity.

Curiously, Latin American societies have increasingly turned to judge-centered solutions. They have apparently discovered the potential of judicial structural reform half a century after their northern neighbor. Against a civil law background, however, this turn has occurred particularly unexpectedly and with a unique flavor. Latin Americans have blazed their own trail not only in empowering the judiciary, but also, in setting its bounds and recognizing its limitations.

In Part VI, the paper shifts gears rather drastically and examines systematic complications that the pursuit of legal entitlements in the region has at times encountered. It notes that these guaranties, along with other juridical precepts, sporadically come to naught due to the precariousness of the rule of law. This predicament might hinder any significant progress towards a brighter future in this area. For instance, the previously mentioned victories could prove to be short lived within such an environment. Beyond adopting new measures or punishing violators more severely, Latin American countries must succeed in the unlikely task of changing the underlying culture. They must enhance the legitimacy of legal norms across the board by renewing their commitment to democracy, as well as to other ideals, such as the rule of law, personal freedom, and (above all) solidarity.

This last section explores these issues and closes with two concessions. First, even if it takes these enormous and improbable steps towards the institutionalization of the principle of legality and ensures the realization of legal entitlements, Latin America will not fully attain social justice. The vindication of rights plays a central, but only limited part in the fight against societal injustice. This battle demands a broader, as well as deeper, engagement, within and without the state, against inequity and marginalization.

Second, the quest for rights may, every now and then, actually prove to be counterproductive with respect to such an emancipatory struggle by reinforcing and perpetuating the very structures that create exclusion in the first place. This metacritique, however, should neither content itself with such an observation nor stop at this initial, negative stage. It should instead strive to become dialectical and, as such, anticipate the supersession [Aufhebung]-namely, both the dissolution and the preservation - of its object. In other words, it should aim at a radical transformation of the current theory and praxis and move towards a new paradigm within which other strategies may complement and, if necessary, eschew the assertion of legal entitlements in order to advance the more ambitious ethical cause. Despite the improbability of the ultimate objective, such a multilayered and relentless undertaking will undoubtedly do much good en route. 


\title{
II. “WHAT'S IN A NAME?": A FAMILY OF RIGHTS REGIMES
}

\author{
Tú, paria en Cuba, solo y miserable, \\ puedes rugir con voz del Continente: \\ la sangre que te lleva en su corriente \\ es la misma en Bolivia, en Guatemala, \\ en Brasil, en Haití...?
}

I will first explain what the expression "Latin America" covers for purposes of this article. The term technically refers to the former colonies of "Latin" nations, such as Spain, Portugal, and France. It became popular during the second half of the nineteenth century, as the French regime embraced it to sell the idea that all these territories belonged together and preferably under the rule of Napoléon III. ${ }^{8}$ France then not only had plans to expand its preponderance throughout the continent, but actually occupied Mexico from 1862 until 1867 and installed Archduke Maximilian of Austria as Emperor. Coincidentally, the Cinco de Mayo holiday commemorates a key, early victory in the protracted and ultimately successful Mexican resistance against the French occupation.'

Nowadays, however, the term "Latin America" usually means Iberian America and thus refers to the New World territories colonized by the nations that occupy the Iberian peninsula, i.e., Spain and Portugal. It rarely incorporates Francophone regions such as Haiti, Martinique, or Quebec. Ironically enough, the concept, which the French crown once propagated in order to amalgamate its areas of control in the Americas with those of other Latin nations, now ordinarily excludes France's former possessions.

This paper deploys the term "Latin America" in this contemporary, albeit inaccurate, sense. It makes use of the more precise, but less current expression "Iberian America," only intermittently. It thus seeks to maintain the former, as familiar and readily comprehensible, while gradually introducing the latter.

The piece focuses on Iberian American countries because, as partial cultural descendants of nations that share so much history, they evince considerable coherence in their conceptions of rights. Spain and Portugal did not simply constitute a single political legal unit during crucial and extended periods of time up to the seventeenth century, but also embraced some of the same sources of law, most notably the Fuero Juzgo and the Siete Partidas, until the nineteenth century. ${ }^{10}$ Former Spanish and Portuguese colonies therefore converged legally during colonial times and frequently developed their law under the influence of each other after independence. ${ }^{11}$ They certainly overlap with countries formerly colonized by France more so than they do with Anglo-American nations; yet undoubtedly less than they do with each other. For instance, some of the key legal institutions, such as the writ

7. NiCOLÁs GUILlÉN, Elegía a un soldado vivo, in CANTOS PARA SOLDADOS Y SONES PARA TURISTAS (1937). Literally: "A pariah in Cuba, alone and miserable, you can roar with the voice of the Continent: the blood that carries you in its current is the same in Bolivia, in Guatemala, in Brazil, in Haiti."

8. Luiz Alberto Moniz Bandeira, ¿América Latina o Sudamérica?, Clarín, May 16, 2005, http:/www.clarin.com/diario/2005/05/16/opinion/o-01901.htm (last visited Apr. 27, 2008).

9. See generally RoBERto CABEllo-ARgandoña, CinCo DE MAYO: A SYMBOL OF MEXICAN NATIONAL RESISTANCE (1997).

10. Id. at 95-100.

11. See generally Rogelio Pérez Perdomo, Notas para una historia social del derecho en América Latina: La relación de las prácticas y los principios jurídicos, 52 REV. COLEGIO DE ABOGADOS P.R. 1 (1991). 
of protection (or amparo), prevail in the Iberian American realm, ${ }^{12}$ but not in its Franco-American counterpart.

Latin American rights schemes bear to each other a family resemblance, in the sense of Wittgenstein. ${ }^{13}$ In other words, they do not have a common element or set thereof, but rather interrelate with each other in a complex manner. They present a "complicated network of similarities overlapping and criss-crossing: sometimes overall similarities, sometimes similarities of detail." ${ }^{14}$ One of these regimes may, for example, resemble most others in constitutionally guaranteeing a sound education, but may differ from them in its rejection of the right to a healthy environment. A few others of these systems may similarly reject the latter entitlement, as well as the former.

Rights cultures in Iberian America generally coincide not only in what they share with each other, but also in what distinguishes them from their counterpart north of the border. To a great extent, this difference stems from the fact that the countries in the region belong to the civil law tradition, while the United States exists within the common law universe. Nonetheless, Iberian American legal orders diverge from the U.S. model specifically, even on substantive and procedural matters that bring them closer to other common law jurisdictions. Hence, they typically reject the death penalty, civil juries, and contingency fees, while embracing constitutional social-welfare entitlements, international human rights, abstract judicial review, and the "English rule" on attorney's fees. Latin American nations have kept considerable distance from the United States partly as a reaction against the overwhelming U.S. hegemony in so many other areas of life.

\title{
III. INTER-GENERATIONAL GUARANTIES: THIN AND THICK
}

\author{
¿A nombre de qué puedo condenar a muerte \\ a otros por lo que son o piensan? \\ Pero ¿cómo dejar impunes \\ la tortura o el genocidio o el matar de hambre? \\ No quiero nada para mí: \\ sólo anhelo \\ lo posible imposible: \\ un mundo sin víctimas. ${ }^{15}$
}

Iberian American countries have constitutionally established similar substantive entitlements. They have enacted first-, second-, and third-generation

12. See infra Section IV.

13. Ludwig WitTgenstein, Philosophische UnTERsuchungen § 67 (G.E.M. Anscombe trans., Basil Blackwell \& Mott, Ltd. 3d ed. 1968). Wittgenstein explains that the members of a family do not all share a particular characteristic or group of characteristics. Some resemble others in the smile, others in the personality, and still others in the tone of voice. They are thus all interrelated without converging on a single feature, "for the various resemblances between the members of a family: build, features, color of eyes, gait, temperament, etc., etc., overlap and criss-cross." Id.

14. Id. at $\$ 66$.

15. José EMIlio PACHECO, Fin de siglo, in FIN DE SIGlo Y OTROS POEMAS (1984). Literally: "In the name of what may I condemn others because of who they are or what they think? But how can one fail to punish torture, genocide, or murder by starvation? I don't want anything for myself. I only yearn for the possibly impossible: a world without victims." 
rights, freely borrowing general ideas, as well as specific formulations, from each other. Of course, the various jurisdictions have maintained significant differences from each other and have in no way coalesced into a single, monolithic system.

First- and second-generation rights are associated, respectively, with the 1966 United Nations' International Covenants on Civil and Political Rights and on Economic, Social and Cultural Rights. ${ }^{16}$ They encompass, on the one hand, entitlements such as equality, due process, privacy, free speech, liberty of association, as well as universal suffrage, and, on the other hand, the right to work, to unionize, to subsistence, to housing, to health, to education, and to culture. Third generation rights, in turn, are entitlements that have emerged subsequently and that regard matters such as consumption, the environment, development, and information. ${ }^{17}$

Upon attaining independence in the nineteenth century, Iberian American nations drafted new constitutions inspired by Spanish, French, and especially, U.S. models. These documents promulgated civil and political rights, which reflected the republican and liberal ethos that prevailed at the time. ${ }^{18}$ Current constitutional charters have preserved guarantees such as freedom of expression, religious liberty, fair trial, and suffrage.

Throughout the twentieth century, Latin American jurisdictions evolved to incorporate social welfare entitlements. Mexico's 1917 Constitution pioneered internationally in recognizing broad socio-economic rights to housing, education, health, and work. ${ }^{19}$ Virtually all other countries in the region followed suit. Curiously, Puerto Rico tried to jump on the bandwagon with its 1952 Constitution, but the U.S. Congress vetoed the social and economic rights proposed by the constituent assembly and ratified by the local electorate. ${ }^{20}$

Latin American constitutions have also embraced third-generation rights. They have guaranteed their citizenry, inter alia, sustainable development, ${ }^{21}$ empowerment

16. G.A. Res. 2200, at 52, U.N. GAOR, 21st Sess., Supp. No. 16, U.N. Doc. A/6316 (Dec. 16, 1966).

17. See generally Jack Donnelly, Third Generation Rights, in PEOPLES AND MINORITIES IN INTERNATIONAL LAW 119, 134-37 (Catherine Brolmann, Rene Lefeber, \& Marjoleine Zieck eds., 1993).

18. See Pérez Perdomo, supra note $11, \S 1$ (b).

19. Constitución Política de los Estados Unidos MeXicanos arts. 123(A)(XII), 34,123 (1917) [hereinafter MEX. CONST.].

20. See Ángel R. Oquendo, Book Review: Pedro A. Malavet, America's Colony, 55 J. LEGAL EdUC. 416-18 (2005).

21. Constitución Política de Bolivia de 1967 art. 133 (1967) [hereinafter Bol. CONST]; CONSTITUIÇÃo dA REPÚBlica Federativa do Brasıl art. 3(II) (1988) [hereinafter BraZ. ConST.];

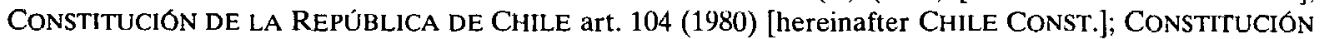
Política de Colombia art. 80 (1991) [hereinafter Colom. Const.]; Cuba Const. arts. 16, 27 (1976); CONSTITUCión POlítica de la República DominiCANa art. 7 (2002) [hereinafter Dom. ReP. CONST.]; CONSTITUCION POLÍtiCa DE LA REPÚBliCA DEl ECUAdOR art. 86 (1998) [hereinafter ECUADOR

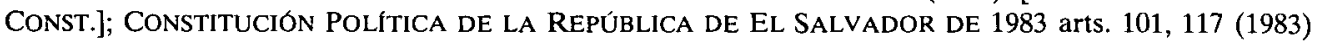
[hereinafter El SAL. CONST.]; CONSTITUCIÓN POLÍTICA DE LA REPúBliCA DE GUATEMALA arts. 97, $119(1,3)$ (1985) [hereinafter GUAT. CONST.]; CONSTITUCIÓN DE LA REPÚBLICA DE HONDURAS art. 329 (1982) [hereinafter HoND. CONST.]; MEX. CONST. art. 25 (1917); CONSTITUCión PolítiCA DE LA REPÚBliCA DE NiCARAGUA [CN.] arts. 99,102 (1987) [hereinafter NiCAR. CONST.]; CONSTITUCIÓN Politica de la República de PANAMÁ arts. 105-07 (1972) [hereinafter PaN. CONST.]; CONSTITUCION Política del Paraguay de 1992 arts. 7, 176 (1992) [hereinafter PARA CONST.]; CONSTITUCIÓN POLÍTICA DEL PERÚ arts. 44, 69 (1993) [hereinafter PERU CONST.]; CONSTITUCION DEL ESTADO LIBRE ASOCIADO DE PUERTO RICO art. 6(19) (1952) [hereinafter P.R. CONST]; CONSTITUCION DE LA REPÚBLICA BOLIVARIANA DE VENEZUELA art. 128 (1999) [hereinafter VENEZ. CONST.]. 
as consumers, ${ }^{22}$ a wholesome environment, ${ }^{2.3}$ as well as informational and cultural self-determination. ${ }^{24}$ The judiciary throughout the region has made clear that these entitlements, like their second-generation counterparts, are not mere aspirations and are certainly not optional. It has repeatedly enforced them programmatically. ${ }^{25}$ In other words, it has called on the authorities to show that they have a program and, more generally, a real commitment. ${ }^{26}$

Constitutional systems frequently formulate first-generation prerogatives as negative and second- and third-generation entitlements as positive. Negative rights take the form of a ban on governmental interference with individual liberties. Classical civil and political entitlements, such as free speech or the right to privacy, exemplify this kind of guaranty. In contrast, positive rights require the state to act rather than to refrain from action. Economic and social rights, including the right to work or to health, provide cases in point, as do many of the previously mentioned third-generation rights.

Certainly, the classification of entitlements as negative and positive is somewhat misleading. Typically negative rights often call on the government to act positively by, for instance, using subsidies or restrictions in order to prevent the speech of the powerful from drowning out that of the weak. Conversely, positive entitlements invariably demand that the authorities abstain from certain action, such as interfering with citizens' right to exercise a profession. Nonetheless, the distinction helpfully underscores the fact that the realization of second- and third-generation entitlements generally requires more elaborate measures and longer-term planning on the part of the state.

Positive rights also raise special questions regarding their judicial enforcement. Is there any role at all for the judiciary to play? Do these entitlements merely define lofty ideals that citizens may not vindicate in court? Or are they instead

22. Constitución Argentina art. 42 (1994) [hereinafter ARg. CONST.]; Braz. CONST. art. 5 (XXXII) (1988); COlOM. CONST. art. 78 (1991); CONSTITUCIÓN POLÍTICA DE LA REPÚBliCA DE COSTA RICA art. 46 (1949) [hereinafter COSTA RICA CONST.]; ECUADOR CONST. art. 92 (1998); El SAL. CONST. art. 101 (1983); GUAT. CONST. art. 119(i) (1985); HOND. CONST. art. 331 (1982); MEX. CONST. art. 28 (1917), PARA. CONST. art. 176. (1992); PERU CONST. art. 65 (1993); VENEZ. CONST. art. 117 (1999).

23. ARG. CONST. art. 41 (1994); BOL. CONST. art. 7(a) (1967); BRAZ. CONST. art. 23(VI) (1988); CHILE CONST. art. 19(8) (1980); ColoM. CONST. art. 79 (1991); COSTA RICA CONST. art. 50 (1949); CUBA CONST. art. 27 (1976); ECUADOR CONST. art. 86 (1998); El SAL. CONST. art. 117 (1983); GUAT. CONST. art. 97 (1985); HOND. CONST. art. 145 (1982); MEX. CONST. art. 4, 25, 73(XXIX)(G) (1917); NICAR. CONST. arts. 60, 102 (1987); PAN. CONST. arts. 114-15 (1972); PARA. CONST. arts. 7-8, 38 (1992); PERU CONST. art. 2(22) (1993); VENEZ. CONST. art. 127 (1999).

24. ARG. CONST. art. 43 (1994); BOL. CONST. arts. 7(b), (e) (1967); BrAZ. ConsT. art. 5(XIV) (1988); COLOM. CONST. art. 20 (1991); COSTA RICA CONST. arts. 30, 89 (1949); DOM. REP. Const. art. 8(10) (2002); ECUADOR CONST. arts. 81, 84 (1998); GUAT. CONST. arts. 35, 68 (1985); HOND. CONST. arts. 15, 182(2) (1982); MEX. CONST. art. 2 (1917); NICAR. CONST. arts. 5, 27, 66, 90 (1987); PAN. CONST. arts. 85-86 (1972); PARA. CONST. arts. 26, 28, 135 (1992); PERU CONST. arts. 2(4), (5) (1993); VENEZ. CONST. arts. 28, $58,101,119-26$ (1999).

25. See, e.g., Urteaga v. National State, 321 F.C.S. 2767 , Corte Suprema de Justicia de la Nación [CJSN], [Sup. Ct.] (1998) (Arg.) (holding that a "lack of legislative regulation [did] not undermine the effectiveness of certain rights" to writ of habeas data to secure information about individuals who disappeared while in authorities' custody); Cochez Farrugia v. Ministry of the Presidency, HD 472-2002 [Sup. Ct.] (Pan.) (interpreting the right to habeas data); Rodríguez Gutiérrez v. President Toledo Manrique, First Chamber, Constitutional Court, November 19, 2004 (Peru) (upholding right to habeas data).

26. See generally ÁNGEL R. OQUENDO, LATIN AMERICAN LAW 324-80 (2006). 
programmatic such that the government has a judicially enforceable obligation to establish a program or plan for their implementation? If so, how much should judges defer to the executive and legislative branches when passing on their efforts in this area?

In the specific case of the right to housing, may a homeless person sue the authorities? Should a tribunal respond to such a complaint by declaring that the state has no justiciable obligation to provide shelter for the plaintiff or anyone else and that the government must decide on its own to what extent it will meet the guaranty in question? Or, alternatively, should the judiciary probe into whether the authorities are taking their duties seriously and whether they have adopted a credible policy to address the housing needs of the citizenry? How might a court that follows this path address the charge that it has arrogated legislative functions to itself?

As already noted, Iberian American tribunals have held positive rights judiciable. Regional constitutional systems actually distinguish themselves, especially from their U.S. counterpart, not only because they recognize these entitlements, but also because they declare them enforceable in court. Recent litigation to vindicate the right to health in Venezuela and elsewhere in the continent illustrates this development rather vividly.

The 1961 Venezuelan Constitution articulates the right to health in the following terms: "People have a right to the protection of their health. The government shall safeguard public health and shall provide means of prevention and care for those who may need them." ${ }^{27}$ The 1999 Constitution takes a step further:

The right to health is socially fundamental. The state shall guarantee this entitlement, as part of the right to life. It shall develop and promote policies to improve the quality of life, the collective well-being, and the access to basic services. The people have a right to the protection of their health. ${ }^{28}$

This provision connects the entitlement in question to the right to life and obligates the authorities to adopt a comprehensive and effective health policy.

The Venezuelan Supreme Court has, accordingly, taken the government to task for not meeting its duties in the area of health. In Rural Psychiatric Institute Virgen del Rosario v. Ministry of Health and Social Welfare et al., a group of clinics sued the Ministry for failing to renew their contracts and for thus infringing upon their indigent mental patients' right to life and health. ${ }^{29}$ The highest tribunal's Political and Administrative Chamber not only agreed with the plaintiffs, but also expressed categorical "disapproval of the Ministry's deplorable conduct.",

This Supreme Court believes that this conduct constitutes an open violation of the rights to life and health of these mental patients. The state cannot effectively guarantee these rights without the necessary resources.

27. VENEZ. CONST. of 1961, art. 76 (superseded).

28. VENEZ. CONST. art. 83 (1999).

29. Rural Psych. Inst. Virgen del Rosario v. Min. Health \& Soc. Wel., Rec. No. 14695 Tribunal Supremeo de Justicia de Venezuela, (Sup. Ct.) (1998), translated and reprinted in OQUENDO, supra note 26, at 327-33.

30. Id. § IV(4)(2). 
Furthermore, defendant has inexcusably failed to meet his duty to care for these unfortunate and neglected Venezuelan citizens who are unable to improve their situation on their own. ${ }^{31}$

The justices insisted that the clinics bore responsibility, along with the authorities, for the protection of the patients' social welfare entitlements.

This Chamber believes that plaintiffs should know that, because they have contracted with the government to care for chronic and indigent mental patients, they share with the state the paramount responsibility of guaranteeing the human rights of these individuals. They must do their utmost to heal and socially reintegrate the patients to the extent possible. In carrying out this all too serious responsibility, they have an ineludible duty to care for, support, and heal these patients. They must respect the patients' dignity and condition as human beings facing the misfortune of being ill and otherwise unassisted. ${ }^{32}$

The Court ordered the government to renew the plaintiffs' contracts and to pay for services rendered after the expiration of the original agreements. ${ }^{33}$

In Cruz del Valle Bermúdez et al. v. Ministry of Health and Social Welfare, the same Chamber upheld the rights of indigent HIV/AIDS patients to receive medicines necessary for the treatment of their illness. ${ }^{34}$ It underscored the obligatory nature of the entitlements in question with the following statement: "all citizensincluding, of course, the plaintiffs in the case at bar-have a right to health. The state has a correlative duty to ensure the effective realization of that right, especially when the health of the indigent is at stake."35 Accordingly, the justices ordered the government to deliver, regularly and periodically, prescribed medication, as well as to carry out or pay for specialized tests. ${ }^{36}$

The Ministry alleged that, in light of its budgetary constraints, it was impossible to finance the treatment in question for the totality of persons suffering from HIV/AIDS. ${ }^{37}$ The Supreme Court impassively replied that the authorities simply had to find the money and called on them to make whatever adjustments in the budget were necessary to meet their constitutional obligations. ${ }^{38}$

The defendant in this controversy, as well as in Virgen del Rosario, answered in a quite typical fashion. When faced with claims based on positive rights, in general, and programmatic entitlements, in particular, the state often pleads insufficiency of funds. The Venezuelan highest tribunal took this defense with a grain of salt in an attempt to preserve the viability of the guaranties at stake.

31. Id.

32. Id.

33. Id.

34. Cruz del Valle Bermúdez v. Min. Health \& Soc. Wel.1, Rec. No. 15.789, Tribunal Supremeo de Justicia de Venezuela, (1999), available at http:/www.escr-net.org/usr_doc/corte_const_venezuela_ sentencia_916.doc, translated \& reprinted in OQUENDO, supra note 26, at 262-323.

35. Id. Analysis (Right to Health, Life, and Access to Science and Technology).

36. Id. Decision (2).

37. Id. Analysis (Right to Health, Life, and Access to Science and Technology).

38. Id. 
In del Valle Bermúdez, Venezuela's justices most significantly ordered "the Ministry of Health and Social Welfare to develop a policy of information, treatment, and comprehensive medical assistance for the benefit of the plaintiffs." Furthermore, they concluded that, because no known cure for the disease existed, "the battle against the disease should focus on prevention." 40 They made specific proposals on this issue:

The state must develop a national prevention program along the following lines:

Educational programs to target vulnerable groups, teenagers, married couples with problems, etc.

Massive provision of information for the community on the disease, its causes, its transmission, and its prevention.

Elaboration of a national plan to make affordable diagnoses possible through the state's medical institutions.

Each of these programs requires special preparation and implementation, taking into account matters such as the general information currently available about the disease, the adequate use of condoms, and the availability of sterile syringes for drug users; the need for special attention for vulnerable groups; the existing efforts at the level of the community; and the role of marriage counseling.

The tribunal articulated the defendant Ministry's duties thus:

The Ministry of Health and Social Welfare must conduct, pursuant to the previously established principles, a thorough study of the basic needs of HIV/AIDS patients and of the different programs available to prevent an increase in the number of people infected. The findings of this study shall be presented to the President of the Republic and the Council of Ministers for consideration in defining the general guidelines for the next fiscal year's budget. ${ }^{42}$

"The goal must be," the opinion explained, "to develop a policy of prevention based on facilitating information to individuals infected with HIV/AIDS, as well as on raising their level of awareness, educating them, and providing comprehensive assistance to them." ${ }^{43}$

39. Id. Decision (3).

40. Del Valle Bermúdez v. Min. Health \& Soc. Wel., Rec. No. 15.789 Analysis (Right to Health, Life, and Access to Science and Technology).

41. Id.

42. Id.

43. Id. Decision (3). 
The Supreme Court merely prescribed rough guidelines for a long-term program of HIV/AIDS treatment and prevention and granted the government sufficient discretion to decide on the details of the required plan. It struck a careful balance between leaving the enforcement of the right to health entirely up to the political authorities and depriving them completely of their decision-making authority in this area. The full realization of programmatic entitlements demands that the judiciary superintend government policies, while allowing state officials sufficient leeway to deploy their resources and expertise efficaciously, as well as creatively.

The opinion in del Valle Bermúdez ends with the following warning: "[t]he authorities must comply with present writ of protection or face sanctions for contempt." ${ }^{\text {"4 }}$ Effective adjudication sometimes requires this kind of threat, whether implicit or explicit, in order to assure the government's compliance.

The Supreme Court should have retained jurisdiction of the case, thereby enabling itself to review the extent to which the Ministry subsequently implemented the remedy, and if necessary, to reconsider its remedial guidelines. Programmatic rights require such prolonged judicial engagement, which ideally should take the form of a conversation between the courts and the authorities. Of course, nongovernmental organizations such as Citizen Action against AIDS (Acción ciudadana contra el SIDA), which filed the complaint, should also play a key role not only in setting the litigation in motion, but also in monitoring the relief.

The 1999 Venezuelan Constitution created a new Supreme Court (Tribunal Supremo de Justicia) and the Constituent Assembly appointed the first members of this body in December of $1999 .{ }^{45}$ The Justices soon confronted additional claims by HIV/AIDS patients. In Glenda López et al. v. the Venezuelan Institute for Social Security, a number of beneficiaries, represented by the same group of attorneys, sued the Institute for Social Security for failing to pay and deliver prescribed HIV/AIDS medicines. ${ }^{46}$ The Constitutional Chamber of the new Court echoed its predecessor in finding that the defendant had "violated the right to health, threatened the right to life, and encroached upon the right to benefit from scientific and technological progress, ${ }^{\prime 47}$ as well as the right to social security. The tribunal similarly rejected the contention that lack of funds or credits might justify the Institute's inaction. ${ }^{48}$

In 2002, the Constitutional Chamber considered a similar action by HIV/AIDS patients against the Institute for Social Security in Antonio Loreto Tabares v. the Venezuelan Institute for Social Security. ${ }^{49}$ Not surprisingly, the body affirmed the holding of Judgment Number 487 of April 6, 2001 (the Glenda López case). ${ }^{50}$ In so doing, it noted "the completeness and clarity of [that] decision" and held "the

44. Id. Decision (4).

45. See Gloria Gonzalez Montero v. National Constituent Assembly, Exp. No. 1142, Tribunal Supreme de Justicia de Venezuela, [TSJ][Sup. Ct.], (2001), partially translated and reprinted in OQUENDO, supra note 26 , at $186-87$.

46. Glenda López v. Venez. Inst. Soc. Sec., Jdt. No. 487 Tribunal Supreme de Justicia de Venezuela, [Sup. Ct.] (2001), available at http://www.escr-net.org/usr_doc/Stcia_venezulea_por_ciento_difusos.doc, translated and reprinted in OQUENDO, supra note 26 , at 346-49.

47. Id. Considerations (2).

48. Id. Considerations (3).

49. Tribunal Supremo de Justicia de Venezuela [TSJ][Sup. Ct.] (2002), Jdt. No. 481 (Venez.).

50. $I d . \S \mathrm{V}(3)$. 
[previously ordered] remedy fully applicable to the complainants in the case at bar." $"$ 11

In a sense, the opinion in Loreto Tabares was superfluous. The precedent was not only admittedly complete and clear, but also expressly applied "to anyone (i) who [was] registered with the Venezuelan Institute of Social Security, (ii) who [had] been diagnosed with the disease HIV/AIDS, (iii) who [met] the legal prerequisites to benefit from the social security system, and (iv) who [had] requested that the Institute deliver the medicines needed for the treatment in question, as well as for the opportunist illnesses, and cover the specialized medical examinations required to treat these illnesses." ".2 Coincidentally, the earlier opinion in del Valle Bermúdez was also on point and equally broad in its scope of application. ${ }^{53}$ Inasmuch as its determinations immediately bind all other Venezuelan tribunals,${ }^{54}$ the Constitutional Chamber ordinarily does not have to decide the same issue over and over again. It probably made repeated pronouncements in López and Loreto Tabares as an indirect and somewhat inefficient way of maintaining jurisdiction over the controversy.

In sum, Venezuelans have made programmatic entitlements, such as the right to health, constitutionally binding on the government and judicially enforceable. They have taken this step practically as a reaction to the state's crass delinquency in this area. In fact, this case does not constitute an isolated instance, but rather a critical trend in Latin America. All Iberian American constitutions recognize the right to health, ${ }^{55}$ along with other positive guaranties. Beyond Venezuela, HIV/AIDS patients throughout the region have likewise seized on this entitlement to try to force the state to provide the medicine and care that they need. They have organized themselves, engaged their fellow citizens, lobbied the executive and legislative branches, and litigated in court. ${ }^{56}$

The political authorities have supported these claims only intermittently. The governments in the region, with the exception of Brazil, provide limited or no coverage for HIV/AIDS. ${ }^{57}$ In contrast, the judiciary has quite consistently sided with claimants and positively enforced the right to health. It has required the state to afford plaintiffs prescribed drugs and therapies and to adopt a long-term plan vis-à$v i s$ the disease.

51. $I d . \S \mathrm{IV}$.

52. Glenda López, Jdt. No. 487, TSJ, at Decistion (3).

53. See del Valle Bermudez v. Min. Health \& Soc. Wel., No. 15789 [Sup. Ct.] (Venez.) (1999).

54. See Venez. Const. art. 334 (1999).

55. See ARG. CONST. art. 42 (1994); BOL. CONST. art. 7, paras. a, k (1967); BRAZIL ConST. arts. 6 , 196-200 (1988); CHILE CONST. art. 19, no. 9 (1980); COLOM. CONST. art. 49 (1991); COSTA RICA CONST. art. 46 (1949), rev. 1996; CUBA CONST. art. 50 (1976); DOM. REP. CONST. art. 8, no. 17 (2002); ECUADOR CONST. art. 23, no. 20 (1998); EL SAL. CONST. arts. 1, 65-70 (1983); GUAT. CONST. arts. 93-95 (1985); HOND. CONST. arts. 145-50 (1982); MEX. CONST. art. 4 (1917), rev. 1994, 1998; NICAR. CONST. art. 59 (1987), rev. 1995; PAN. CONST. arts. 105-07 (1972), rev. 1983, 1994; PARA. CONST. art. 68 (1992); PERU CONST. art. 7 (1993); P.R. CONST. art. 2, § 20 (1952); URU. CONST. art. 44 (1988), rev. 1989, 1997; VENEZ. CONST. arts. $83-85$ (1999).

56. UNAIDS, NGO Perspectives on Access to HIV-Related Drugs in 13 Latin American and Caribbean Countries, UNAIDS/98.25, Nov. 19 1998, available at http://data.unaids.org/Publications/IRCpub01/JC100-NGO-Perspectives_en.pdf.

57. See Avert: Averting HIV and AIDS, http://www.avert.org/aidslatinamerica.htm (last visited Mar. 28, 2008); Red Hispana de Derechos Humanos en vih-sida y minorías sexuales, http:// www.convencion.org.uy/menu2-050.htm (last visited Mar. 28, 2008). 
In its 1995 Judgment T-271/95, for instance, the Colombian Constitutional Court held "that the petitioner, [who suffered from HIV/AIDS, had] a right to receive the totality of the prescribed treatment." "\$8 The tribunal concluded "that the duty to protect the health and preserve the life of the patient must take priority and would become meaningless if there were no possibility of enjoying all the treatment prescribed by physicians." 59 The Colombian justices determined that the denial of care constituted discrimination against the plaintiffs, both as people infected with the HIV virus and as indigent citizens. ${ }^{60}$ Moreover, the Colombian Constitutional Court's Judgment T-505/92 established that the denial of integral healthcare to HIV/AIDS patients amounted to a failure to fulfill the obligation to "prevent, as well as contain the propagation of, the disease."

Similarly, Peru's Constitutional Court in its Judgment 2945-2003-AA/TC of the year 2004 ordered "the inclusion of petitioner among the patients to receive full HIV/AIDS treatment, including medicines and analyses, as recommended by the physicians of the hospital under the supervision of the Ministry of Health., ${ }^{, 62}$ It called on the authorities to consider "contributions to the budget for the Anti-AIDS Plan a priority investment." ${ }^{63}$ The tribunal maintained jurisdiction over the dispute and enjoined "the hospital directors to update the Court every six months on petitioner's treatment."

In the same opinion, the Peruvian Constitutional Court offered an engaging discussion concerning the nature of the rights at stake.

Social and economic rights, namely, welfare rights, such as social security, public health, housing, education, and other public services, are necessary because they constitute social instruments that the state provides in order to enable individuals to attain complete self-determination. Citizens vindicate these entitlements by demanding that the government undertake whatever measures may be required in order to meet the corresponding societal goals. Because they often require financial support for their realization, social rights are not always enforceable exclusively within the legal system.

Contrary to the traditional understanding, these entitlements are not merely programmatic norms that may only be enforced in a mediate manner and that differ from civil and political rights that allow for

58. Diego Serna Gomez v. el Hospital Universitano del Valle "Evaristo Garcia", Sent. No. T-271/95, Exp. No. T-62714, (Const. Ct.)(Colom.)(1995), II-Legal Grounds, para. 13.

59. Id. para. 14.

60. Id. para. 15 .

61. Diego Serna Gomez v. el Hospital Universitano del Valle "Evaristo Garcia", (Const. Ct.)(Colom.)(1992), 28/8/1992, Sent. No. T-505/92, Exp. No. T-2535, (Colom.) Legal Grounds, para. 8.

62. Azanca Alheli Meza Garcia v. Ministerio de Salud del Perú, Tribunal Constitucional, (Const. Ct.), 20/4/2004, Exp. No. 2945-2003-AA/TC (Peru), Resolutions, para. 2.

63. Id. para. 3 .

64. Id. para. 4. 
immediate enforcement. In fact, welfare rights must be minimally respected as an indispensable condition for the enjoyment of civil and political rights. Accordingly, without education, health, and a decent quality of life, there would be no social liberty or equality. The legislature and the judiciary must therefore understand that the realization of these two kinds of entitlements must take place jointly and interdependently.

Of course, social rights require that the state set up basic public services, as well as that the citizenry contribute taxes in order to provide public financing for the underlying social policy. In any case, social rights impose concrete obligations on the authorities. The government must adopt constant and efficient measures for a progressive enforcement of these entitlements under conditions of equality for the entire population.

Consequently, we must interpret social rights as genuine claims of the citizen against the state, if we are to recognize the legal validity of constitutional imperatives and the relevance of the Constitution.

This new vision of social rights makes it possible to do justice to principles such as solidarity and human dignity, which constitute fundamental pillars of the social state and the rule of law. ${ }^{65}$

Peru's Constitutional Court, hence, acknowledged that the vindication of social welfare rights could only take place with the cooperation of the authorities and in a progressive manner. The tribunal insisted, however, that these crucial entitlements were not optional and that they were judicially enforceable. It used the case at hand to illustrate exactly how courts should implement these guaranties.

In Costa Rica, the Constitutional Chamber of the Supreme Court announced, in its 1997 Judgment 5934 and in five parallel opinions of the same year, "that the Costa Rican state [had] a duty, which [derived] from the principles of justice and solidarity that [underlay] the constitutionally established social security system and from the mission that the Constitution [imposed] on the Costa Rican Social Security Fund, to provide effective medical care for AIDS patients."

65. Id. paras. $10-15$.

66. William García Alvarez v. Caja Costarricense de Seguro Social, Judgment 5934 Sala Constitucional de la Corte Suprema de Justicia, [Sup. Ct. Const. Ch.] (1997) Considerations, V-Conclusion; Luis Guillermo Murillo Rodríguez v. Caja Costarricense de Seguro Social, Judgment 6096 Sala Constitucional de la Corte Suprema de Justicia, [Sup. Ct. Const. Ch.] (1997); Juan Ignacio Mora Salas v. Caja Costarricense de Seguro Social, Judgment 8245 Sala Constitucional de la Corte Suprema de Justicia, [Sup. Ct. Const. Ch.] (1997); Gerardo Vargas Garcias v. Caja Costarricense de Seguro Social, Judgment 8204 Sala Constitucional de la Corte Suprema de Justicia, [Sup. Ct. Const. Ch.] (1997); Fernando Zeledón Pérez v. Caja Costarricense de Seguro Social, Judgment 8422 Sala Constitucional de la Corte Suprema de Justicia, [Sup. Ct. Const. Ch.] (1997). 
tribunal invoked not only Article 73 of the Constitution, but also Articles 22, 16, and 9 of the Universal Declaration of Human Rights, the American Declaration of the Rights and Duties of Man, and the International Covenant of Economic, Social, and Cultural Rights, respectively. ${ }^{67}$ While acknowledging that its decisions might critically overburden the health system, the Court expressed the hope "that [the] crisis [would] ultimately encourage the development of novel solutions, as expected by AIDS patients and by Costa Rican society in general."

In eight subsequent opinions also issued in 1997, Costa Rica's Supreme Court reaffirmed its holding in Judgment 5934. ${ }^{69}$ It severely criticized the Social Security agency for its utter disregard of a most fundamental right: "[d]efendant is clearly violating the principle of equality, inasmuch as it provides medicines for treatment only to people who obtain a favorable judgment from the Constitutional Chamber and turns down all other individuals, including petitioner." ${ }^{\text {,70 }}$ While deciding eight disputes in 1998 along nearly identical lines, the tribunal additionally warned "that there should be no discrimination against the complainant, who [like] the plaintiff in [Judgment 5934, had] requested the antiretroviral medicines from the Costa Rican Social Security Fund, and [was] entitled to them, so long as he [had] a prescription from his attending physician."

In a decision of 2004, the Costa Rican justices established that the authorities had an obligation to afford HIV/AIDS patients the prescribed treatment

67. Id.

68. Id.

69. Roger Martín Cervantes de la Rocha v. Caja Costarricense de Seguro Social, Judgment 8058, Sala Constitucional de la Corte Suprema de Justicia [Sup. Ct. Const. Ch.] (1997); Gerardo Enrique Elizondo Salgado v. Caja Costarricense de Seguro Social, Judgment 8304, Sala Constitucional de la Corte Suprema de Justicia [Sup. Ct. Const. Ch.] (1997); Edgar Francisco Briceño Torres v. Caja Costarricase de Seguro Social, Judgment 8647, Sala Constitucional de la Corte Suprema de Justicia [Sup. Ct. Const. Ch.] (1997); Edgar Marin Aguilar a favor de William Marín Aguilar (Prez) v. Caja Costarricase de Seguro Social, Judgment 8648, Sala Constitucional de la Corte Suprema de Justicia [Sup. Ct. Const. Ch.] (1997); Freddy Fernández Fernández v. Caja Costarricase de Seguro Social, Judgment 8755 , Sala Constitucional de la Corte Suprema de Justicia [Sup. Ct. Const. Ch.] (1997); Hernán Castillo Salazar v. Caja Costarricense de Seguro Social, Judgment 8756, Sala Constitucional de la Corte Suprema de Justicia [Sup. Ct. Const. Ch.] (1997); Carlos Rodrigo Sánchez Jiménez v. Caja Costarricense de Seguro Social, Judgment 8757, Sala Constitucional de la Corte Suprema de Justicia [Sup. Ct. Const. Ch.] (1997); Kattia Aguilar Gómez v. Caja Costarricense de Seguro Social, Judgment 8758, Sala Constitucional de la Corte Suprema de Justicia [Sup. Ct. Const. Ch.] (1997).

70. Id. Considerations.

71. Judgments 452-53, 456, 767-69, 771-72 [Sup. Ct. Const. Ch.] (Costa Rica) (1998), Considerations. Próspero Mena Vilchez v. Caja Costarricense de Seguro Social, Judgment 452, Sala Constitucional de la Corte Suprema de Justicia [Sup. Ct. Const. Ch.] (1998); Marco Antonio Rojas Quesada v. Caja Costarricense de Seguro Social, Judgment 453, Sala Constitucional de la Corte Suprema de Justicia [Sup. Ct. Const. Ch.] (1998); Marco Castillo Rojas a favor de Marcedonio Evelio Piñar Gómez v. Caja Costarricense de Seguro Social, Judgment 456, Sala Constitucional de la Corte Suprema de Justicia [Sup. Ct. Const. Ch.] (1998); Francisco Javier Rojas Rojas v. Caja Costarricense de Seguro Social, Judgment 767 , Sala Constitucional de la Corte Suprema de Justicia [Sup. Ct. Const. Ch.] (1998); Freddy Villalobos Vargas v. Caja Costarricense de Seguro Social, Judgment 768, Sala Constitucional de la Corte Suprema de Justicia [Sup. Ct. Const. Ch.] (1998); Raúl Ernesto Gutiérrez Villareal v. Caja Costarricense de Seguro Social, Judgment 769, Sala Constitucional de la Corte Suprema de Justicia [Sup. Ct. Const. Ch.] (1998); Mainor Navarro Arce v. Caja Costarricense de Seguro Social, Judgment 771, Sala Constitucional de la Corte Suprema de Justicia [Sup. Ct. Const. Ch.] (1998); Hannier Alejandro Chacón a favor de él Mismo v. Caja Costarricense de Seguro Social, Judgment 772, Sala Constitucional de la Corte Suprema de Justicia [Sup. Ct. Const. Ch.] (1998). 
immediately." "The directors of the Costa Rican Social Security Fund and affiliated hospitals, as well as clinics, [had] a duty and a personal responsibility ... to adopt and implement administrative and organizational measures to put a definite end to the delay in the delivery of health services ...."73 The Court called attention to Article 71 of the Constitutional Jurisdiction Act, which authorizes the imposition of a prison term of three months to two years or a fine on whoever defies a writ of protection. $^{74}$

Finally, Argentina's Supreme Court has taken a most active role in this area. In the year 2000, it upheld a writ of protection, which was secured by the Benghalensis Association and other non-governmental organizations on behalf of AIDS victims, compelling the Ministry of Health and Social Action to deliver a number of prescribed medicines to these individuals. ${ }^{75}$ In 2001, the tribunal ordered a private prepaid health clinic, Omint Corporation and Services, to reinstate a previously terminated AIDS patient and offer treatment and medication for his illness. ${ }^{76}$ In 2002, the Argentine justices issued a preliminary injunction enjoining the Institute for Medical Assistance of the Province of Buenos Aires to provide Verónica Sandra Dieguez and José Luis López with medically prescribed anti-AIDS drugs. ${ }^{7}$ The Court entered a similar order in favor of Silvia Elena Rogers in $2003 .^{78}$

Not all Latin American courts have been equally receptive to this kind of claim. Chile's Supreme Court, for example, dismissed Náyade Roja Vera's suit seeking AIDS treatment and medication from the Metropolitan Health Services Provider Sur Oriente and the Ministry of Health, then under the leadership of Michelle Bachelet. In their opinion, the justices declared "that the problem at stake [involved] public health policy, which should be defined and applied by the Ministry's officials, who [were] best qualified to regulate access to the requested services and to assess issues such as cost and available funding." sustained the state's actions because it determined that they were neither illegal nor arbitrary. ${ }^{80}$

The Chilean plaintiffs subsequently took their grievance to the Inter-American Commission on Human Rights and obtained preliminary relief. "In its communication of November 20, 2001, the [body] informed the Chilean State that the aforesaid individuals urgently needed basic assistance from state institutions in order to secure the drugs needed for their treatment; it therefore requested the

72. Julio Alvarado Morera a favor de Marco Antonio Briceño Campos v. Caja Costarricense de Seguro Social, Judgment 8633, Sala Constitucional de la Corte Suprema de Justicia [Sup. Ct. Const. Ch.] (2004).

73. Id. IV-Efficacy, Efficiency, Continuity, Regularity, and Adaptation in Public Health Services.

74. Id. VI-Conclusion.

75. Corte Suprema de Justicia [CSJN], 2000, "Benghalensis Ass'n v. Min. of Health and Social Action", (A-186/LXXXIV) (Arg.).

76. Roberto Eduardo Etcheverry v. Omint Corp. \& Services, CSJN, [Sup. Ct.] (2001) (E. 34/XXXV) (Arg.).

77. CSJN [Sup. Ct.], (D. 2014/XXXVIII) 2002, "Verónica Sandra Dieguez \& José Luis López v. the Province of Buenos Aires", (Arg.).

78. Corte Suprema de Justicia [CSJN] [Sup. Ct.], 2003, "Silvia Elena Rogers v. the Prov. B.A.", (R. 671/XXXIX) (Arg.).

79. Corte Suprema, 2001, "Nayade Rojas Vera v. Min. of Health", 20/7/2001, Rec. No. 3599, Diario Oficial de la República de Chile, (2001), available at http:/www.anfitrion.cl/actualidad/relacion/ jurisp.noticiosa/fallo10.html.

80. Id. 
adoption of urgent measures to ensure them access to medicines needed for their survival and to medical examinations for the regular monitoring of their health conditions." 2001, the State described the preliminary steps taken at the Ministry of Health and reported that Juan Pablo Améstica, Manuel Orlando Farías, and Náyade Orieta Rojas Vera were receiving medication and undergoing examinations in order for their health conditions to be monitored by the State's services.",2

In El Salvador, HIV/AIDS patients filed for a writ of protection on April 28, 1999, before the Constitutional Chamber of the Supreme Court. ${ }^{83}$ Upon the tribunal's failure to issue a decision, the plaintiffs turned to the Inter-American Commission and secured a temporary remedy on February 29, 2000. "On June 26, 2000 , the Board of Directors of the Salvadoran Social Security Institute authorized the procurement of the triple antiretroviral therapy for persons who are HIVpositive or have AIDS in that country." The Commissioners held the petition admissible in $2001 .^{86}$ The Commission issued similar preliminary injunctions in favor of complainants from Bolivia and Ecuador in 2002, and from Guatemala in 2004. ${ }^{87}$

All in all, most Latin American high tribunals have taken HIV/AIDS patients' claims seriously. They have made clear that social welfare rights - such as the right to health-impose judicially enforceable obligations on the state. They have acknowledged, however, that the implementation of these entitlements differs from that of civil and political rights in that it demands more collaboration with and deference to the authorities.

In fact, judges throughout the region have tended to favor targeted remedies, such as ordering the government to administer specific drugs and treatments, over structural injunctions on prevention and long-term healthcare policy. The former kind of relief involves less judicial supervision, engagement, and intrusion than the latter. Nonetheless, it similarly requires courts to review the state's sanitary, medical, and budgetary priorities, as well as its official determinations. These opinions may pave the road not only to broader constitutional control over the government's social welfare programs, but also to more resolute adjudication of third-generation rights.

In this area, domestic and international law interact in an intricate and intense way. First, national courts do not hesitate to invoke both domestic and international norms. They apply international precepts directly, i.e., without waiting for enabling legislation, and with precedence over local statutory law. Second, transnational decisionmakers regularly and effectively intervene to ensure that the government honors its citizens' entitlements. These cases show that the general interconnection

81. Inter-Am. C.H.R., Annual Report, $\operatorname{III(C)(1)(b)~(2001),~available~at~http://www.cidh.oas.org.~}$

82. Id.

83. Jorge Odir Miranda Cortez v. El Salvador, Case 12.249, Inter-Am. C.H.R., Report No. 29/01, paras. 1, 38 (2001).

84. Inter-Am. C.H.R., Annual Report, supra note 81, III(C)(1)(i).

85. Id.

86. Jorge Odir Miranda Cortez v. El Salvador, Case 12.249, Inter-Am. C.H.R., Report No. 29/01 (2001).

87. Inter-Am. C.H.R., Annual Report, III(C)(1)(b), (h) (2002), available at http://www.cidh.oas.org; Luis Rolando Cuscul Pivaral v. Guatemala, Case 642/03, Inter-Am. C.H.R., Report No. 32/05 para. 7 (2005). 
between domestic and international legal systems takes place with respect to positive as well as negative rights. This theme will reappear and preponderate in Part $\mathrm{V}$ of this work.

Over the last decade or so, Iberian American tribunals have proceeded in a similarly assertive manner in other areas, such as anti-discrimination, cultural selfdetermination, land reform, education, workplace conditions, information access, consumer prerogatives, and environmental protection. This development has produced a paradigm shift away from a conception of the judiciary as passive, reactionary, and hopelessly inane. To a considerable extent, the widespread and grave injustices that prevail in the region, the failure of the executive and legislative branches to respond, and (especially) the aggressiveness of civil society have forced the judiciary to take a more activist, progressive, and effective role. In essence, nongovernmental collectivities have drawn on the courts and other autonomous institutions-such as the public ministry, the ombudsman, or administrative agencies - in order to confront the authorities on issues of policy and entitlements. Naturally, these groups have simultaneously fought for their causes in the realm of politics and out on the streets. ${ }^{88}$

These judicial victories certainly do not constitute aberrations; they occur ever more frequently across the continent. Nonetheless, they have not even remotely attained universality. Latin American tribunals all too often fail to do justice to programmatic guaranties and other safeguards. They must therefore continue transforming themselves, perhaps by finding inspiration in and building on these extraordinary successes. By taking this path, the judiciary might not only motivate the authorities to commit to their citizens' rights, but also contribute significantly to the advancement of the rule of law throughout the region.

Objectors could naturally reject these decisions as highly problematic instances of judicial activism. They could contend that the judiciary is not technically equipped and lacks the democratic legitimacy to make these complex and contentious policy determinations. Iberian American activist judges seem to face even more of a predicament in this sense today than did the judiciary in the United States during 1960s and 1970s insofar as they are enforcing not negative, but rather positive rights, which ordinarily entail additional levels of intricacy and controversy.

Paradoxically, the Latin American opinions in question have generated less of an uproar than their earlier U.S. counterparts. The explanation undoubtedly lies in the fact that the latter involved an issue that had divided the society as a whole for over a century: namely., racial justice. At any rate, some courts in the United States have also implemented second- and third-generation entitlements and have engaged in "public-law" adjudication, even when confronting first-generation claims."

A response to the objection at stake might focus on the extent to which many Iberian American governments outrageously disregard their citizens' rights and thereby force the judiciary to intervene as a matter of emergency. Arguably, U.S. tribunals have occasionally had to react to similarly shocking delinquency on the part of the authorities, at least until the official termination of segregation. Unfortunately, a defense of judicial engagement along these lines would ultimately fail. It might provide an excuse for individual judges acting under exceptional

88. See generally OOUENDO, supra note 26, at 324-80.

89. See generally Abram Chayes, The Role of the Judge in Public Law Litigation, 89 HARV. L. REV. 1281 (1976) (discussing the expanding role of the American judiciary in "public-law" adjudication). 
circumstances, but certainly would not justify permanent judicial involvement on behalf of individual and collective entitlements.

A more promising rejoinder would start by noting that all constitutions in Latin America emphatically endorse the positive guaranties at issue. Given such a constitutional framework, courts do not really have an option: they must redress any existing violation. They may not simply express regrets or cynically advise plaintiffs to try anew petitioning other branches of government.

For instance, when critically ill, indigent AIDS patients sue for their right to health and show that the state has refused to take even minimal action on their behalf, the judiciary has an obligation to act. Judges bound by the notion of legality may not recognize the entitlement and then deny a remedy. They must regard the asserted guaranty as more than an empty pledge and, to that end, use all their power for its effective implementation. They should not shy away from ordering, if necessary, the provision of basic care, the delivery of medicine, or the adoption of longer-term measures.

Of course, a tribunal should exercise its prerogatives cautiously. It should generally defer to the authorities and refrain from second-guessing them when they promote an adequate, albeit improvable, plan. It should allow for a gradual and progressive fulfillment of the commitments in controversy, instead of expecting immediate satisfaction.

If the court rules against the defendants, it should merely formulate broad guidelines. It should grant state officials ample leeway to produce a solution on their own. As evidenced by the previously canvassed decisions, judicial intervention may take the form of dialogue rather than that of a unilateral dictate.

Nonetheless, it would be wrongheaded to pursue a rigid definition of the bounds of valid adjudication in this area. The same example illustrates this point. The judiciary would lack crucial flexibility if, for instance, it could only order the administration of medication. It should also be able to assume a constructive and forward-looking role by fashioning preventive arrangements or calling for special therapies.

In this context, tribunals have to oversee, though certainly not control, policy making. While they should avoid rearranging the administration's priorities, they may intervene to address extreme governmental neglect or arbitrariness. For example, judges may compel the state to pay attention to the AIDS crisis, but not to devote more resources to this disease than to others, such as cancer.

Significantly, Latin American courts confront institutional constraints too. They must not only wait for a litigant to invoke their jurisdiction, but also work with other self-standing bodies, such as the Public Ministry, ${ }^{90}$ the Human Rights

90. See ARG. CONST. art. 120 (1994); BOL. CONST. arts. 124-26 (1967); Braz. CONST. arts. 127-30 (1988); CHILE CONST. art. 80A (1980) (as amended, 1997); COLOM. CONST. arts. 117-18, 275-84 (1991); Law 7333 (Costa Rica) (1937) (As Amended, 1997), art. 149; CuBA Consr. arts. 127-30 (1976) (as amended, 1992); DOM. REP. CONST. art. 66 (2002); ECUADOR CONST. arts. 214-19 (1998); EL SAL. CONST. arts. 191-94 (1983); GUAT. CONST. arts. 251-52 (1985).; HOND. CONST.arts. 228-31 (1982); MEX. CONST. art. 102(A) (1917); NICAR. CONST. art. 138(8) (1987) (as amended, 2000); PAN. CONST. arts. 216-21 (1972); PARA. CONST. arts. 244-46 (1992); PERU CONST. arts. 158-60 (1993); CONSTITUCIÓN POLÍTICA DE LA REPÚBLICA ORIENTAL DEL URUGUAY DE 1967 arts. 314-16 [hereinafter URU. CONST.]; VENEZ. CONST. arts. $247-50,284-86$ (1999). 
Procurator, ${ }^{91}$ or the Popular Defender. ${ }^{92}$ These entities perform a function at trial that is analogous to that of a special master or an expert witness in the United States, although they usually enjoy separate standing in addition to independence from both the judge and the parties. By contributing expertise, as well as a self-determining perspective, they counterbalance the adjudicator's operational deficiencies. Still, these bureaucracies operate with a democratic deficit similar to that of the judicial branch, inasmuch as their staff is not directly accountable to the electorate or the government. Like the judiciary, they must derive their legitimacy partly from the reasonableness and the prudence of their performance, but principally from the constitutional structure, which establishes the guaranties at bar and commands the participation of these bodies in enforcement.

At this juncture, skeptics could radicalize their position and censure the incorporation of second- and third-generation rights into the constitution. Nonetheless, they would ultimately lack a compelling argument to demand that the citizenry refrain from exercising this constitutional option. They could hardly condemn a community that enthusiastically embraced positive entitlements and reasonably entrusted the judiciary to play a supportive part in the realization stage.

A full discussion of these issues would require a whole new article. Beyond an elaboration on the themes already mentioned, it would demand a detailed analysis of the inner workings of adjudication. It would have to evolve into an elucidation of how tribunals ineluctably and rightly move, without necessarily encroaching upon the province of the legislature or the executive, from mere application to creation of legal norms, as well as from deliberation on principles to assessment of policies.

This subsection need not march all the way down such an argumentative path; it solely purports to suggest the overall plausibility of judicial vindication of positive entitlements. The underlying effort consists of fathoming an emerging Iberian American trend towards a robust endorsement of these guaranties and in advocating the intensification of this development. Once again, this piece does not identify the conception of rights in the region with the present praxis, but instead with the potential for the future, and proceeds more normatively than descriptively.

\section{Procedural Claims: Beauty and the Beast}

\section{A harmonia secreta da desarmonia. Quero não o que está feito, mas o que tortuosamente ainda se faz. ${ }^{93}$}

Up to this point, this article has focused on substantive law. As a result, it has failed to explain fully the institutional implementation of the rights in question and has sounded rather opaque. To address this problem, one must descend to procedure, namely, to what the civil law tradition denominates "adjectival" or

91. See El Sal. ConSt. art. 194 (1983) (Procurator for Human Rights); GuAT. Const. arts. 273-75 (1985), (Procurator for Human Rights); HoND. CONST. art. 59 (1982) (National Human Rights Commissioner); MEX. CONST. art. 102(B) (1917) (National Human Rights Commission); NiCAR. CONST. art. 138(29) (1987) (Procurator for Human Rights).

92. See ARG. CONST. art. 86 (1994); BOL. CONST. arts. 129-31 (1967); COLOM. CONST. arts. 281-84 (1991); ECUADOR CONST. art. 96 (1998); PARA. CONST. arts. 276-80 (1992); PERU CONST. arts. 161-62 (1993); VENEZ. CONST. arts. 280-83 (1999).

93. Clarice Lispector, Água Viva 12 (1973). Translation: "The secret harmony of disharmony. I want not what is already made, but rather what is still in the process of being tortuously made." 
"formal" law. These terms call for an interpretation that tracks their Latin roots. The adjective (adiectum), accordingly, does not subserviently describe, but rather adds to or complements, the substantive. The form (forma), in turn, does not entail superficiality; it instead constitutes the shape and the beauty of the content.

Hence, a full account of the rights regimes south of the border requires an examination of procedural entitlements. Upon considering these guaranties, one immediately perceives strong convergence and significant uniqueness in Latin America. Furthermore, one realizes that substantive entitlements are intricately intertwined with their procedural counterparts and that one cannot fully understand the former without at least a most elementary grasp of the latter.

Exclusively substantive analyses of rights inevitably operate at an abstract level. They become more concrete when they also focus on procedure. This additional step makes it possible to examine a given entitlement in action and to reveal what it is all about. Such an examination may even show that the right in question, in fact, differs radically from its similarly labeled counterparts in other jurisdictions. Though by the same name, the rose may not smell as sweet. ${ }^{94}$

For example, when scholars simply declare that the citizenry enjoys free speech, they are not passing on much information. To add specificity to their account, they must explain how a particular individual may vindicate this guarantee. May such a person draw on state-owned means of dissemination, or subsidies, to transmit her message or to obtain data that she needs? What restrictions may the government legitimately impose? May the citizen in question, under certain circumstances, compel the private media to assist her? If the authorities or non-governmental actors fail to assist her as required by law or even thwart her attempts at communication, does she have recourse? Must she turn to an administrative agency first or may she immediately take to the courts? How does she formulate her claim? What kind of relief may she obtain? How may she enforce the remedy? By entertaining these procedural questions, legal analysts flesh out the idea of liberty of expression.

This piece deploys the concept of procedure in a broad sense. It does not focus merely on judicial, administrative or arbitrative proceedings, but also on transactions prior to any formal or informal dispute resolution. In any case, an analysis of rights that excluded the latter would be too general and, ultimately, incomplete, even if it included the former. Hence, the basic point applies to both implementation phases. In the end, the very line that separates substance from procedure becomes tenuous. The two realms interfuse intensely in practice.

This section considers several procedural mechanisms for the implementation of the previously discussed guaranties, illuminating the substance of those entitlements by showing how they actually come to life within the legal order. As previously noted, this turn to procedure demonstrates both the similarities and the differences between Latin American rights schemes. It specifically leads to three institutions that represent momentous steps forward and that hopefully will continue to flourish all over the region.

94. See William Shakespeare, Romeo And Juliet, act 2, sc. 2 ("What's in a Name? That which we call a rose by any other name would smell as sweet."). 


\section{A. The Writ of Protection or Security}

\section{Comovo-me com esta América Latina, quando lhe consulto seus enredos salpicados de tristeza, de generosidade, de exuberância. ${ }^{95}$}

The discussion begins with the amparo, or writ of protection. This special procedure developed in Mexico in the nineteenth century to enable individuals and groups to vindicate their legal entitlements. It has gradually and steadily taken hold in other Iberian American legal systems and is now available throughout the continent, from Tijuana to Tierra del Fuego.

Most countries, like Mexico, denominate this action amparo, a word that means protection or shelter. The Colombian Constitution uses instead the term tutela, ${ }^{96}$ which translates into guardianship or defense, while the Chilean charter opts for the concept recurso de protección, or (literally) "protection recourse." The Brazilian Constitution, in turn, speaks of a mandado de segurança, i.e., "security mandate."

Even when the name varies, the underlying procedure remains essentially the same. It enables claimants summarily to vindicate constitutional and other entitlements. The court must give priority to these cases and apply a special set of procedural rules.

Moreover, the decision typically binds only the litigants. For instance, when the judge holds the challenged act or law unconstitutional, he does not establish a precedent. Another individual subsequently facing a similar situation would have to re-litigate the issue. She may naturally cite the preceding opinion as a source of persuasive reasons, but not as a binding norm.

Of course, the details vary enormously from one country to the next. In Argentina and Brazil, for instance, the proceeding unfolds strictly summarily and allows exclusively documentary proof. ${ }^{99}$ The tribunal basically treats the request for the writ as a motion for summary judgment. In Mexico and most other jurisdictions, the parties may introduce all kinds of evidence, including testimonial. Furthermore, Latin American systems diverge on issues such as whether the suit lies only against state action, whether it applies only to constitutional rights, and whether it allows challenges to judicial decisions. Finally, Argentina and Paraguay, unlike the totality of their regional neighbors, authorize judges generally to invalidate unconstitutional statutes in these causes. ${ }^{100}$

Nonetheless, Iberian American legal systems converge broadly in their conception of the writ of protection, thus distancing themselves from their counterpart north of the border. In the United States, plaintiffs typically bring constitutional claims through an ordinary action under the rules of civil procedure. In Latin America, they file for a writ of protection or security, which resembles the

95. Translation: "Latin America moves me, whenever I sound her tangles, which are sprinkled with sadness, generosity, and exuberance."

96. Colom. CONST. art. 86 (1991).

97. ChIle CONST. art. 20 (1980). Curiously, Chilean lawyers use the word "amparo" to denominate the writ of habeas corpus. See, e.g., JORGE MARIO QUINIZIO FIGUEIREDO, Justicia CONSTITUCIONAL EN CHILE 78-79 (2000).

98. BRAZ. CONST. art. 5 (LXIX) (1988).

99. BRAZ. CONST. art. 5 (LXIX) (1988). Brazil's Constitution, in turn, establishes that the writ lies to protect "summarily and clearly ascertainable" entitlements.

100. ARg. CONST. art. 43 (1994); C. Civ. Pro. art. 582. (Paraguay) (1988). 
German constitutional complaint (Verfassungsbeschwerde) ${ }^{101}$ in that it involves a special, extraordinary proceeding. In many Iberian American countries, unlike in the United States, a specialized constitutional tribunal, whether a Constitutional Court or the Constitutional Chamber of the Supreme Court, hears final appeals in these cases. To some extent, these tribunals resemble the German Constitutional Court and the French Constitutional Council. As already mentioned, most Latin American courts, unlike their U.S. counterparts, do not have the power, when deciding these suits, to declare statutes unconstitutional with general or erga omnes effect.

A brief examination of the Mexican writ of protection, which constitutes the original and most complex variant, makes it possible to acquire a general sense of how this institution operates. The experience of other countries in the region derives either directly or indirectly from that of Mexico. Nonetheless, the particularities of the procedure differ significantly from one jurisdiction to the next.

The writ of protection is one of the crowning achievements of the Mexican legal order. It emerged in the nineteenth century, first appearing in the 1841 Yucatán Constitution. It entered Mexico's national law as part of the 1847 Reform Act, which modified the 1824 Federal Constitution. It represents an attempt to incorporate judicial review, as formulated by the U.S. Supreme Court in Marbury $v$. Madison, ${ }^{102}$ into the Mexican constitutional universe. It also, however, bears the mark of Spanish, French, and prior Mexican law. ${ }^{103}$

Classically, when a person in Mexico feels that the authorities have infringed upon her rights, she does not file an ordinary complaint, but rather requests a writ of protection. She thus sets in motion an extraordinary process, which unfolds with exceptional speed and simplicity. If she prevails, the court orders the state to stop the violation.

In Mexico, Articles 103 to 107 of the Constitution broadly govern the writ of protection. The Writ of Protection Act addresses the details. Constitutional Article 103(I), which grants federal courts jurisdiction over protection suits, authorizes the vindication of all individual rights. The writ of protection has a similarly broad scope in Argentina, Bolivia, Brazil, Guatemala, and Paraguay. ${ }^{104}$ In most other Latin American countries, however, the action lies only when constitutional or fundamental entitlements are at stake. ${ }^{105}$

101. F.R.G. CONST. art. 93 (4)(a) (1949); see HÉCTOR FIX-ZAMUdio, El JUICIO DE AMPARO

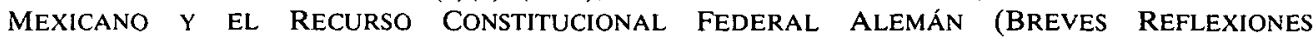
COMPaRAtivas), Nuevo Serie Year XXVI, No. 77461-488 (May-Aug. 1993).

102. 5 U.S. 137 (Cranch) (1803).

103. HECTOR FIX-ZAMUdIO, ENSA YOS SOBRE EL DERECHO DE AMPARO 22-25 (1999).

104. See ARG. CONST. art. 43 (1994); Bol. CONST. art. 19 (1967); Braz. CONST. art. 5 (LXIX) (1988); GuAT. CONST. art. 265 (1985); PARA. CONST. art. 134 (1992).

105. See CHILE CONST. art. 20 (1980); COLOM. CONST. art. 86 (1991) (Chile allows the action to protect only a specific list of constitutional entitlements, while the Colombian writ secures exclusively "fundamental constitutional rights."); COSTA RICA CONST. art. 48 (1949); ECUADOR CONST. art. 95 (1998); El SAL. CONST. art. 247 (1983); HOND. CONST. art. 183 (1982); NICAR. CONST. art. 188 (1987); PAN. CONST. art. 50 (1972); PERU CONST. art. 200(2) (1993); Ley 16.011, art. 1, 7 de Deciembre de 1988 (Uru.) (El Salvador, Honduras, Nicaragua, Panama, Peru, and Uruguay limit the writ to constitutional prerogatives.); VENEZ. CONST. art. 27 (1999) (Costa Rica, Ecuador, and Venezuela authorize protection suits to safeguard constitutional plus fundamental international, inalienable, and ordinary international rights, respectively.); Productos Avon, Inc. v. 2nd Ch., Labor Ct., Nat. Dist., [Sup. Ct.] (Dom. Rep.) (1999) 
Under Article 107(II) of the Mexican Constitution, as well as Article 76 of the Writ of Protection Act, the judicial decision in a protection suit usually does not have general or erga omnes effect. ${ }^{106}$ In other words, the court makes a determination on the illegality of the challenged official action not per se, but only with respect to the parties in the concrete dispute under consideration. Subsequent petitioners do not have a precedent on which they can rely to make their cases. They must instead argue anew, as if there had been no prior judicial decision. They may cite that preceding opinion as a source of persuasive reasons, but not as a binding norm.

Mexican scholars denominate this "principle of relativity"107 the "Otero formula" because jurist and politician Mariano Otero introduced it in the 1847 Reform Act. ${ }^{108}$ The precept reflects Mexico's characteristically civil law concern about excessive judicial power. It does not preclude judges from setting aside unconstitutional laws, but limits the reach of the invalidation to the case at hand. It thus makes a compromise between two alternatives: full-fledged judicial review and absolute deference to legislative enactments. As explained earlier, other Iberian American jurisdictions, with the exception of Argentina and Paraguay, take a similar approach.

The Mexican Writ of Protection Act itself establishes a curious exception to this general ban on stare decisis. The Supreme Court and circuit courts may posit case law binding on lower tribunals, so long as they meet the following strict conditions. Supreme Court holdings "constitute case law if supported by five consecutive, uninterrupted decisions, which at least eight [out of eleven] justices of the Plenum or four [out of five] justices of the competent Chamber have approved."109 Circuit court panel holdings, in turn, "constitute case law if supported by five consecutive, uninterrupted, and unanimous decisions."

A few other Latin American jurisdictions also empower their highest tribunal to issue case law only under limited circumstances. For instance, Article 43 of the Guatemala's Writ of Protection, Habeas Corpus, and Constitutionality Act establishes the following: "The Constitutional Court's interpretation of constitutional and legal norms in three consecutive decisions establishes legal doctrine that other tribunals must respect." 111 Similarly, two-thirds of the Brazilian Supreme Court may issue a binding holding "after reiterated prior decisions on point" whenever lower courts are divided and there is a situation of "serious legal uncertainty." 12 Hence, the Brazilian Constitution simply calls for "reiterated" decisions, not for a specific number. In any event, it takes an additional step away from the civil-law bias against judicial review without giving up the prejudice altogether.

(In the Dominican Republic, plaintiffs may file a protection complaint to assert any fundamental right.).

106. See MEX. CONST. art. 107(II) (1917).

107. Ignacio Burgoa adopts this term. IgnACio BuRgOA, El Juicio DE AMPARo 275, 529 (1994).

108. Id.; FIX-ZAMUDIO, supra note 103, at 159.

109. Ley de Amparo (Writ of Protection Act), Diario Oficial de la Federación, art. 192, Jan. 10, 1936

(Mex.).

110. Id.

111. Ley de Amparo, Exhibición Personal y de Constitucionalidad (Writ of Protection, Habeas Corpus, and Constitutionality Act), Decreto 1-86, art. 43 (1986) (Guat.).

112. BRAZ. CONST., as amended, art. 103-A (1988). 
Some Iberian American high courts have unrestricted authority to establish precedents. In Costa Rica and Venezuela, the decisions of the Constitutional Chamber of the Supreme Court bind all other chambers and tribunals; yet they do not oblige the Constitutional Chamber itself. ${ }^{113}$ Under the influence of the United States, the Puerto Rican Supreme Court has long adhered to the doctrine of stare decisis and therefore binds itself as well as other tribunals. ${ }^{114}$ Nonetheless, Puerto Rico's legal order, like that of Cuba and unlike all others in the region, does not provide for a writ of protection.

Mexico's writ of protection, in its traditional form, simply enables individuals to secure their fundamental rights. Nevertheless, it has developed and expanded enormously. Presently, it is possible, in the words of Mexican jurist Héctor FixZamudio, "to challenge any action, resolution or precept in [the Mexican] legal system." "115 Accordingly, this institution has given rise to a family of related, but distinct procedural institutions.

Fix-Zamudio breaks the suit down into the following categories: habeas corpus, the writ against laws, cassation, as well as administrative and agrarian actions. ${ }^{116}$ There are probably as many ways to categorize this institution as there are to skin a cat. One way of explaining the writ most clearly, however, is to focus on the kind of act it purports to contest.

The paradigmatic protection suit challenges a public official's actions that allegedly impinge upon the claimant's rights. For instance, a plaintiff may seek the writ against a policeman who fines her for delivering a subversive speech in a public square. Of course, if she ended up in jail as a consequence, her action would function as a habeas corpus petition.

More generally, individuals may oppose the conduct of anyone working within the state's administrative apparatus, so long as they have no recourse to judicial review within the relevant agency. ${ }^{117}$ They must exhaust administrative remedies, unless the prerequisites for a stay of the challenged determination exceed those imposed by the Writ of Protection Act. ${ }^{118}$

The importance of the writ of protection against administrative acts has diminished with the expansion of administrative tribunals, at both the federal and the state level. ${ }^{119}$ If the law provides for such a forum, complainants must first litigate there. ${ }^{120}$ They may thereafter contest the decisions through a protection suit against adjudicative acts, as described infra.

Litigants may bring a protection action against administrative acts performed by the judiciary or the legislature. For example, if a court arbitrarily refuses to allow

113. Venez. CONST. art. 335 (1999); Ley de la Jurisdicción Constitucional, Law No. 7135, art. 13 (1989) (Costa Rica).

114. See ex parte García Fernández, 44 D.P.R. 296 (1932), Capestany v. Capestany 66 D.P.R. 74 (1946); see also González Natal v. Merck Sharp \& Dohme Química de Puerto Rico, Inc., 2006 TSPR 2 (2006) (Denton, J., concurring).

115. FIX-ZAMUDIO, supra note 103 , at 19.

116. Id. at $30-47$.

117. MEX. CONST. art. 107(IV) (1917).

118. Id.

119. FIX-ZAMUDIO, supra note 103, at 42.

120. MEX. CONST. art. 107(IV) (1917). 
an attorney to litigate within its jurisdiction, the lawyer may file for this administrative writ. An individual may similarly proceed against lawmakers if they illegitimately deny her access to key legislative documents.

The writ of protection against laws is most clearly of U.S. inspiration. It covers not only statutes, but also executive decrees and administrative regulations. It diverges from its U.S. analogue in that it usually does not have general or erga omnes effect. In other words, when Mexican judges declare the challenged legal provision unconstitutional, they typically void it only with respect to the parties. The law ordinarily remains applicable to other individuals.

In these actions, individuals sue the institution responsible for the law's adoption, such as the legislature, the executive branch, or an administrative agency. They must, like all other protection plaintiffs, demonstrate an actual injury to their legal interests. ${ }^{121}$ In particular, they may not challenge a law that is not selfexecuting, i.e., that requires an additional legislative or administrative act to become effective. ${ }^{122}$

If a judge violates an individual's rights in the course of deciding a case, the affected person may seek a writ of protection against the decision. For instance, if a court unjustifiably exonerates an employer who discriminates against a female employee, the latter may bring this kind of action. If the judicial determination rests on a law, the affected party may rely on this writ to invalidate the application of the legal provision in question. Once again, the declaration of unconstitutionality only benefits the parties before the tribunal.

Normally, litigants must wait not only until the end of their trial, but also of their appeals before initiating a protection suit. ${ }^{123}$ They may file their claim immediately after the original proceeding, only if they risk irreparable harm. ${ }^{124}$ In general, they may contest judgments by administrative as well as ordinary tribunals. Furthermore, they may seek the invalidation of statutes, decrees, and regulations.

This kind of petition ultimately grants litigants an additional level of appellate review. Plaintiffs must file the suit with the competent circuit panel, rather than a district court. ${ }^{125}$ Ordinarily, they may not appeal the panel's decision. Nonetheless, Article 107(IX) of the Mexican Constitution authorizes the Supreme Court to review these cases when a "law's constitutionality or the direct interpretation of a constitutional precept is at stake" and the appeal raises "important and transcendent issues." In Mexican Sugar Workers Union v. Abel Hernández Rivera, for instance, Mexico's highest tribunal allowed the defendants to appeal a circuit court's grant of a writ of protection against a labor tribunal's judgment under Articles 395 and 413 of the Federal Labor Act. ${ }^{127}$

121. MEX. CONST. art. 73(V) (1917).

122. Id. art. 73(VII).

123. Id. art. 107 (III).

124. Id.

125. Id. art. $107(\mathrm{~V}),(\mathrm{VI})$.

126. Id. art. 107(IX).

127. Mexican Sugar Workers Union v. Abel Hernández Rivera, Segunda Sala de la Suprema Corte de Justicia [S.C.J.N.], Direct Writ of Protection 1124/2000 on Appeal, Semanario Judicial de la Federación y su Gaceta, Novena Epoca, tomo XIII, Dec., 2001, Tesis 2a./J. 64/2001, Página 315 (Second Chamber) (Mex.). 
Curiously, the appellate protection action enables individuals to challenge any judicial decision, not just those that undermine specific rights. It rests on the controversial idea that any misapplication of the law constitutes a violation of the legality principle set forth in constitutional Articles 14 and 16 and of the corresponding individual rights. Accordingly, the tribunal corrects errors in the application of the law, somewhat like the French Supreme Court, namely, the Cour de Cassation. In fact, this suit against mistaken legal determinations was influenced by and ultimately replaced the Mexican cassation procedure, which had arrived from France via Spain. ${ }^{128}$

A couple of Latin American jurisdictions have instituted the writ of protection not by constitutional or statutory amendment, but rather by judicial determination. In Argentina, for instance, the Supreme Court created the action in the 1950s in two cases that Argentine lawyers still cite and refer to using the English term "leading cases." In Angel Siri v. Police Commissioner, District of Mercedes, the tribunal issued the writ in favor of a publisher whose newspaper was arbitrarily closed down by the police. ${ }^{130}$ The plaintiff had originally sought a writ of habeas corpus and lost at trial because he had failed to show any impairment to his physical liberty. ${ }^{131}$ Finding a "clear infringement upon ... freedom of the press and the right to work established in Articles 14, 17, and 18 of the Constitution," the justices decided to provide a remedy. ${ }^{132}$ They rejected "traditional doctrine relegating to ordinary proceedings (administrative or judicial) the protection of prerogatives not strictly included in habeas corpus" and established the writ of protection for such cases. ${ }^{133}$

In Samuel Kot, L.L.C., v. Arón Fistein, the "owner of a textile plant" filed a protection suit against a group of employees who had taken over the premises upon the dismissal of two union officials in the aftermath of a strike. ${ }^{134}$ The Supreme Court expressed considerable consternation about the workers taking the law into their own hands, but much less concern about the employer's violation of labor laws. After all, the employees seized the factory in response to the firing of two union officials in the aftermath of the strike.

Citing the right to an effective remedy under Article 8 of the Universal Declaration of Human Rights, the Argentine justices reiterated their support for the writ of protection. ${ }^{135}$ Furthermore, they described the role of the judiciary in the following terms.

Judges must use the expeditious writ of protection to redress all clearly illegal restrictions on any of the basic human rights whenever relying on the ordinary judicial or administrative procedures would result in a serious

128. FIX-ZAMUDIO, supra note 103, at 197-234.

129. See, e.g., Jorge A. Rojas, Un "nuevo molde" para el amparo, 1 REVISTA LATINOAMERICANA DE DERECHO 425, 426 (Mex.) (2004); Jorge Alejandro Amaya, Aportes a los procedimientos de proteccion al consumidor que consagra el Artículo 42 de la Constitución Nacional, REVISTA JURfDICA I (UCES).

130. Corte Suprema de Justicia de la Nación [F.C.S.], CSJN, 27/12/1957, "Ángel Siri v. Police Commissioner, District of Mercedes”, (1957-239-459) (Arg.).

131. Id.

132. Id.

133. Id.

134. Corte Suprema de Justicia [CSJN], CSJN, 5/11/1958, "Samuel Kot, L.L.C. v. Arón Fistein" (1958241-921) (Arg.).

135. Id. 
and irreparable harm. Of course; judges must act deliberately and prudently - as they regularly do when carrying out many of their other preeminent duties-so as to avoid deploying this extremely summary constitutional procedure to decide questions calling for extensive debate and for resolution through ordinary proceedings. ${ }^{136}$

Significantly, the brethren established the availability of the writ against private parties and thus started a trend that most Iberian American countries have followed. ${ }^{137}$ Nonetheless a significant number of jurisdictions in the region still impose a state action requirement. ${ }^{138}$

In 1966, the Argentine Congress passed Law 16986, codifying the writ of protection and regulating its procedural details. The statute incorporates the basic principles that the leading cases, Siri and Kot, established. Thus, the statutory writ of protection covers rights that fall outside the writ of habeas corpus, operates when other legal means would not suffice to address the alleged violation, and involves a summary proceeding. ${ }^{139}$

Still, Law 16986 deviates from case law in certain significant respects: it authorizes the writ only against state officials, ${ }^{140}$ and it merely protects rights "that the Constitution recognizes explicitly or implicitly." 141 The Congress eliminated the former restriction in 1967, when it amended the Code of Civil and Commercial Procedure to allow the writ against private parties. Article $321(1)$ provides specifically for an "extra summary procedure ... against acts or omissions of private parties that presently or imminently impair, restrict, alter, or threaten in an arbitrary or illegal manner the rights established by the Constitution." ${ }^{142}$

In 1994, Argentina radically transformed its Constitution and, inter alia, constitutionalized the writ of protection, thus precluding elimination or substantial alteration of the writ through ordinary legislation. ${ }^{143}$ Law 16986 remains in force to the extent that it does not contradict the constitutional text. Constitutional Article 43 now reads, in part:

Any person may commence an expeditious procedure to obtain a writ of protection against acts or omissions of public authorities or private parties that arbitrarily or illegally impair, restrict, alter, or threaten the rights established by this Constitution, a treaty, or a law. The writ will be

136. Id.

137. See ARG. CONST. art. 43 (1994); BOL. CONST. art. 19 (1967); COLOM. CONST. art. 86 (1991); ECUAdor CONST. art. 95 (1998); PARA. CONST. art. 134 (1992); PERU CONST. art. 200(2) (1993); Writ of Protection Act, Law 16011, art. 2 (Dec. 29, 1988) (Uru.); Writ of Protection Act (Venez.) (1987), art. 2; Sup. Ct. Decree 1552 (Chile) (1976), arts. 3, 12; see also Productos Avon, Inc. v. 2nd Ch. (1999).

138. See BRAZ. CONST. art. 5 (LXIX) (1988); Hond. CONST. art. 183 (1982); MEX. Const. art. 103(I) (1917); NICAR. CONST. art. 188 (1987); PAN. CONST. art. 50 (1972); Constitutional Jurisdiction Act (Costa Rica) (1989), art. 29; Constitutional Procedures Act, art. 12 (El Sal.) (1960); Writ of Protection, Habeas Corpus, and Constitutionality Act (Guat.) (1986), art. 8.

139. Writ of Protection Act, Law No. 16986, arts. 1, 2(a), 2(d), Oct. 18, 1966, [1967-A] A.L.J.A. 500 (Arg.).

140. Id. arts. $1,8$.

141. Id. art. 1.

142. Cód. Proc. Civ. Y Com., Law No. 17454, art. 321(1), Sept. 20, 1967 (amended 2001) [1967-A] A.L.J.A. 533, 570 (Arg.).

143. ARG. CONST. art. 43. (1994). 
available only if there is no other more appropriate procedure. The judge may declare unconstitutional the norm upon which the infringing actions or omissions are based. ${ }^{144}$

This provision leaves no doubt that plaintiffs may sue private parties and vindicate conventional and statutory entitlements, as well as constitutional prerogatives.

Moreover, the constitutional precept underscores the subsidiary nature of the action, reiterating that the writ is available only "if there is no other more appropriate procedure." ${ }^{145}$ In this regard, the Argentine legal system takes a position similar to that of other Latin American jurisdictions. ${ }^{146}$ Of course, Article 43 of the Argentine Constitution uniquely insists that the alternative procedure must be "more" and not just equally "appropriate" in order to preclude the writ of protection.

Towards the close of the twentieth century, the Dominican Republic remained one of the few Iberian American countries whose legal system did not provide for a writ of protection. The Dominican Supreme Court changed this situation quite dramatically in 1999 when it declared the protection suit a right under the American Convention of Human Rights and, therefore, automatically part of Dominican positive law. ${ }^{147}$

In Productos Avon, Inc., v. Second Chamber of the Labor Court of the National District, plaintiffs filed a protection suit alleging that the Second Chamber violated due process in an action for illegal dismissal of two of their employees. ${ }^{148}$ They cited, inter alia, conventional Article 25(1): “[e]veryone has the right to simple and prompt recourse, or any other effective recourse, to a competent court or tribunal for protection against acts that violate his fundamental rights recognized by the constitution or laws of the state concerned or by this Convention . . . "149

In holding for the complainants, the Dominican high tribunal declared: "There should be a special mechanism to enforce rights. This Supreme Court has the power to establish an adequate procedure if the legislature has failed to do so." proceeded to delineate procedural parameters for protection suits.

The plaintiff must request the writ within fifteen days of the occurrence of the conduct at issue. The hearing must take place within three days of the filing of the complaint. If the suit clearly lacks any merit whatsoever, the judge must state so in the record and shelve the complaint. Under these circumstances, the petitioner does not have a right to appeal. Upon

144. Id.

145. Id.

146. See, e.g., Writ of Protection Act, Law No. 16986, art. 1, Oct. 18, 1966, [1967-A] A.L.J.A. 500 (Arg.); Bol. CONST. art. 19 § IV (1967); COLOM. CONST. art. 86 (1991); Constitutional Procedures Act, art. 12 (1960) (El Sal.); PARA. ConST. art. 134 (1992); Writ of Protection Act, Law No. 16011, art. 2 (Dec. 29, 1988) (Uru.); Writ of Protection Act, art. 5 (1988) (Venez.).

147. See Productos Avon, Inc. v. Second Chamber of the Labor Ct. of the Nat'l Dist. Supreme Court of Justice of Dom. Rep. (1999).

148. Id.

149. American Convention of Human Rights art. $25 \S 1$, Nov. 22, 1969, O.A.S.T.S. No. 36, 1144 U.N.T.S. 123.

150. Productos Avon, Inc. v. 2nd Ch. (1999), Considerations. 
completing his consideration of matter, the judge must produce a judgment within five days. The parties must appeal before the competent appellate court within three days of the judgment. They must meet the same deadlines that we have established for the trial, as well as for the decision. The protection proceeding will entail no court costs. ${ }^{151}$

On the basis of the language of Article 25(1), the Court concluded that protection plaintiffs may challenge the actions of judges, as well as those of private individuals. ${ }^{152}$ While many Iberian American jurisdictions ban the latter kind of suit, several disallow the former. ${ }^{153}$ The Dominican justices, therefore, took an expansive position in the transcontinental debate on the scope of the writ of protection.

The protection suit has evolved into a characteristically Latin American institution, as well as into a fundamental part of the rights culture throughout the continent. It has attained universal resonance not only because of the importance of legal entitlements everywhere, but also because of the inefficiency and unreliability of ordinary process in many areas of the region. The writ has principally compensated for these dysfunctions in the law, though it has occasionally compounded them. The final section of this article explores these matters further.

The discussion in this subsection makes it possible to grasp the sense in which substantive and procedural claims interact most intensely. Referring back to the previous example, the liberty in question, viz. free speech, will take on a specific character in a jurisdiction that recognizes the writ of protection. It will normally be enforceable against private parties, through a special procedure, and with relative speed. Significantly, individuals will ordinarily have a right to demand not that the government realize freedom of expression generally, but simply that it refrain from interfering with their discrete attempts to express themselves freely.

All in all, the writ of protection represents a major accomplishment. It has enabled Iberian American legal orders not only to compensate for their overall inefficacy, but also to move away from a rigid civil-law model that banned all judicial review. The main drawback is that this procedural device usually does not allow the judiciary to enunciate a precedent that other litigants may subsequently invoke. The natural tendency of judges to consistency and to follow decisions of higher courts counteracts this shortcoming only minimally. As explained in the next two subsections, unconstitutionality suits, along with collective actions, have often helped to offset this deficiency in a more substantial manner. In any case, Iberian American societies would be well-advised to follow the lead of Argentina and Paraguay and grant erga omnes effect to judicial determinations in protection or security cases.

151. Id. Resolutions, II.

152. Id. Considerations.

153. See, e.g., Ley No. 7135, Ley de Jurisdicción Constitucional (Constitutional Jurisdiction Law), (Costa Rica); ECUAdOR CONST. art. 95 (1998); Constitutional Procedures Act, art. 13 (1960) (El Sal.); PARA. CONST. art. 134 (1992); PERÚ CONST. art. $200 \S 2$ (1993); Law No. 16011, art. 1 a (1988) (Uru.). 


\title{
B. Unconstitutionality Actions
}

\author{
Voy a seguir la huella \\ sobre el mar de una estrella \\ que se perdión ${ }^{154}$
}

Unconstitutionality actions, through which courts conduct abstract judicial review exist virtually everywhere in Latin America and contribute crucially to the protection of rights. ${ }^{155}$ They traveled from Continental Europe to the New World, though the imported grape ended up producing a different wine when exposed to a new soil and climate.

In many jurisdictions this kind of constitutional challenge may take place only once, either before or after enactment of the law in question. For instance, the French constitutional council must scrutinize legislative projects under the National Assembly's consideration prior to their final approval. ${ }^{155}$ Similarly, the Chilean Constitution empowers the Constitutional Court to assess the constitutionality of "organic constitutional laws" solely before congressional passage. ${ }^{157}$ Other Latin American countries allow such review shortly after promulgation. Mexico requires this constitutional monitoring to occur within thirty days, while Nicaragua imposes a sixty-day limit. ${ }^{158}$ Peru recently extended the deadline from six months to six years. ${ }^{159}$ Most nations in the region, however, follow the German model, inasmuch as they do not establish a deadline. ${ }^{100}$ Article 551 of the Paraguayan Code of Civil Procedure explicitly declares that constitutionality challenges are not subject to any statute of limitations. ${ }^{161}$

Tribunals do not, of course, initiate this type of review. They must wait for a party to file a complaint. Both the French and the German constitutions grant standing exclusively to high-profile individuals or institutions, such as the head of the executive branch or a delegation of lawmakers. ${ }^{162}$ Similarly, Bolivia, Brazil, Chile, Costa Rica, Ecuador, Guatemala, Mexico, and Peru permit only select parties to contest national laws generally. ${ }^{163}$

154. Dulce María Loynaz, El perdedor, in Versos (1950). (Literally: "I shall follow the traces, upon the sea, of a lost star.")

155. See BOL. CONST. art. $120 \S 1$ (1967); BRAZ. CONST. art. 103 (1988); CHILE CONST. art. 82 § 1-2 (1980); COLOM. CONST. art. $241 \S 1$ 1, 4-5 (1991); COSTA RICA CONST. art. 10 (1949); DOM. REP. CONST. art. 67 \$ 1 (2002); ECUADOR CONST. art. 277 (1998); El SAL. CONST. art. 183 (1983); EL SAL. CONST. arts. 266-67 (1985); HOND. CONST. art. 184-85 (1982); MEX. CONST., as amended, art. $105 \S$ II, Diario Oficial de la Federación [D.O.], 5 de Febrero de 1917 (Mex.); NICAR. CONST. art. 187 (1987); PAN. CONST. art. $203 \S$ 1 (1972); PARA. CONST. art. 132 (1992); PERÚ CONST. art. $200 \$ 4$ (1993); URU. CONST. art. $256-61$ (1967) VENEZ. CONST. art. $336 \S 1-4$ (1999).

156. 1958 CONST. art. 61 (France).

157. CHILE CONST. art. $82 \S \S 1,2$.

158. MEX. CONST. art. 105 (1917); Writ of Protection Act, Law 49 art. 10 (1988) (Nicar.).

159. Const. Ct. Org. Act, Law 26435 art. 26 (1995) (Peru).

160. See Bol. Const. art. 120; Braz. Const. art. 103; COlOM. Const. art. 241; Costa RiCA CONST. art. 10; DOM. REP. CONST. art. 67; ECUADOR CONST. art. 277; El SAL. CONST. art. 183; GUAT. CONST. arts. 266-67; HOND. CONST. art. 184.

161. C. Civ. Pro., Law 1337 art. 551 (1988) (Para.).

162. 1958 CONST. art. 61 (France); GRUNDGESETZ [GG] [CONSTITUTION] art. 93 (F.R.G.).

163. See Bol. CONST. art. 119 (the President, lawmakers, the Attorney General, the Public Defender); BRAZ. CONST. arts. 102-03 (the President, the Leadership of the Senate, the Chamber of Deputies or a state legislature, state governors, the General Procurator, the national Bar Association, a 
Some of these countries, however, open up the process to a wider range of plaintiffs under certain circumstances. Costa Rica's Constitutional Adjudication Act allows any person to sue, so long as "the case involves either matters that by nature do not lead to individual and direct injury or the defense of interests that are general or pertain to the collectivity as a whole." ${ }^{164}$ Ecuador allows a group of one thousand citizens to file this kind of complaint, while Peru posits five thousand as the threshold number. ${ }^{165}$ Finally, Guatemala allows any person to bring suit so long as she has the assistance of at least three attorneys. ${ }^{166}$

A plurality of Latin American jurisdictions confers standing in these actions rather liberally. In the Dominican Republic, Honduras, Paraguay, Uruguay, and Venezuela, any interested party may commence this kind of litigation. ${ }^{167}$ The Colombian, Salvadoran, Nicaraguan, and Panamanian constitutions, in turn, empower any citizen to do so. ${ }^{168}$ In particular, they do not require plaintiffs to show individual harm in order to proceed. Hence, the unconstitutionality action has generally and uniquely evolved into a broadly available mechanism to redress violations of constitutional principles.

The Colombian Constitution authorizes the Constitutional Court to "decide unconstitutionality suits filed by citizens against laws" or executive decrees. ${ }^{169}$ It allows the tribunal to decide in these cases whether substantive and procedural violations of the Constitution have taken place. ${ }^{170}$ The Procurator General must intervene in these controversies and file a brief within thirty days. ${ }^{171}$ The tribunal, in turn, ordinarily has sixty additional days to issue its opinion. ${ }^{172}$

political party, a union, or a class entity); CHILE CONST. art. 82 (the President, the head of either legislative chamber, or a fourth of the legislature); Ley No. 7135, Ley de Jurisdiccion Constitucional (Constitutional Jurisdiction Law), (Costa Rica) (1989), art. 75 (ordinary citizens on behalf of collective interests, the General Comptroller, the General Procurator, the Attorney General, or the Public Defender); ECUADOR CONST. arts. 276-77 (the President, the Congress, the Supreme Court, a group of a thousand citizens, or a single citizen with the Public Defender's approval); Writ of Protection, Habeas Corpus, and Constitutionality Act, Decree 1-86 (Guat.) (2002), art. 134 (the Bar Association, the Public Ministry, the Human Rights Procurator, any person assisted by three Attorneys); MEX. CONST. art. 105 (thirty-three percent of either chamber of Congress and the Procurator General); PERU CONST. arts. $200-03$ (the President, the Attorney General, the Public Defender, one fourth of Congress, and a group of at least fivethousand citizens).

164. Ley No. 7135, Ley de Jurisdiccion Constitucional (Constitutional Jurisdiction Law), (Costa Rica) (1989).

165. ECUADOR CONST. art. 277; PERU CONST. art. 203.

166. Writ of Protection, Habeas Corpus, and Constitutionality Act, Decree 1-86 art. 134 (2002) (Guat.).

167. DOM. REP. CONST. art. 67 ("an interested party"); HOND. CONST. art. 185 ("individuals who have suffered an injury to their directly, personal, and legitimate interests"); C. Civ. Pro., Law 1337 art. 550 (1988) (Para.) ("any person injured in her legitimate rights"); URU. CONST. art. 258 ("individuals who have suffered an injury to their directly, personal, and legitimate interests"); Ley Organica del Tribunal Supremo (Supreme Court Organic Act), art. 21 (2004) (Venez.) ("any person or legal entity whose rights or interests have been affected.").

168. Colom. Const. art. 241; El Sal. Const. art. 183; NiCAR. CONST. art. 187; PAN. Const. art. 203 $\S 1$.

169. COLOM. CONST. art. $241 \S \S 4-5$.

170. Id.

171. Id. art. $242 \S \S 2,4$.

172. Id. art. $242 \$ 4$; Decree 2067, art. 6, Sept. 4, 1991 (Colom.). 
A justice of the Constitutional Court serves as rapporteur and must first decide, within ten days, whether the complaint meets all formal requirements. ${ }^{173}$ Upon a finding of admissibility, any citizen may present arguments in favor of, or against, the constitutionality of the challenged statute within ten days. ${ }^{174}$ When constitutional rights are at stake, the Public Defender may also take a position on the matter. ${ }^{175}$ The Court must notify the President or the Congress, depending on whether the plaintiff is challenging a decree or a statute. ${ }^{176}$ It may also alert the state institutions that participated in the elaboration or enactment of the challenged precept, ${ }^{177}$ and it must grant them ten days to argue for the constitutionality of the law. ${ }^{178}$

The rapporteur may examine any relevant evidence within ten days. ${ }^{179}$ Alternatively, the Court may delegate this function to another justice. ${ }^{180}$ Following this evidentiary phase, the rapporteur prepares a draft opinion, upon which her colleagues must deliberate for at least five days, except in cases of national emergency. ${ }^{181}$ The tribunal may decide by a majority to hold a public hearing in which the litigants have a "brief but reasonable amount of time" to clarify and expound on their arguments. ${ }^{182}$ The Procurator General may also partake in this proceeding $^{183}$ along with organizations and experts on the issue. ${ }^{184}$

The Constitutional Court decides by majority and dissenters may file a separate opinion. ${ }^{185}$ If a majority rejects the rapporteur's position, the Chief Justice may call upon another justice to draft an opinion for the tribunal. ${ }^{186}$ The final decision appears, along with any concurrences or dissents, in the Constitutional Court's Gazette. ${ }^{187}$

The Court's judgment is obligatory, as well as unappealable, and constitutes res judicata; its reasoning binds all other tribunals. ${ }^{188}$ Nonetheless, individuals may secure a writ of protection subsequent to a declaration of constitutionality by showing that the norm in question is unconstitutional as applied to them or that it violates a constitutional right not considered by the justices. ${ }^{189}$ In these cases, the trial judge may request the Constitutional Court to clarify its original holding. ${ }^{190}$

The Court has played an extremely energetic and progressive role in protecting a wide variety of constitutional rights in Colombia. It has relied mostly on the writ

173. Decree 2067, art. 6 (1991) (Colom.).

174. Id. art. 7 .

175. Id.

176. Id. art. 11; COLOM. CONST. art. 244.

177. Decree 2067, art. 11.

178. Id.

179. Decree 2067, art. 10 (1991) (Colom.).

180. Id.

181. Id. art. 9.

182. Id. art. 12 .

183. Id.

184. Id. art. 13.

185. Decree 2067 art. 14 (1991) (Colom.).

186. Id. art. 17.

187. Id. art. 18.

188. Id. arts. $21,23,49$.

189. Id. art. 24.

190. Id. 
of protection, but also considerably on the unconstitutionality suit. It has, for instance, combated sexism in civil law by declaring various articles in the Code unconstitutional. In 1999 and 2001, respectively, it struck down the Civil Code's Article 140(7), which nullified marriages between "an adulterous woman and her accomplice," and Article 173, which forbade the immediate remarriage of women who were pregnant at the time of their divorce. ${ }^{191}$

The Colombian Constitutional Court has confronted in this way even seemingly harmless discrimination. In Yolima Milena González Bernal v. Civil Code, Article $126,{ }^{192}$ the tribunal invalidated the challenged provision, which establishes the following: "Marriages shall take place before the municipal judge of the woman's vicinity in the presence of two witnesses under oath."193 The justices held that inasmuch as they could find no constitutionally acceptable and compelling rationale for "the preference for the prospective wife's domicile," this provision encroached upon the principle of sexual equality of Articles 13 and 43 of the Colombian Constitution. They basically rewrote the statute when they declared that the responsible official must be the municipal judge of the vicinity of either of the spouses. ${ }^{194}$

In González Bernal, the Constitutional Court struck down, sua sponte, interrelated Article 131 of the Civil Code, which reads:

If the prospective spouses live in different districts or if one of them has lived at the current common residence for less than six months, the judge of the woman's vicinity shall demand that the judge of the man's vicinity, first, issue the edict mentioned in the previous Article and, in due course, send it over and confirm that it was posted for fifteen consecutive days .... ${ }^{195}$

"This provision," according to the tribunal, "presents the same constitutional defect ... identified with respect to Article 126: It presumes that the marriage will be performed in the future wife's domicile." 196 The justices, once again, did not hesitate to draft a constitutionally acceptable alternative.

Hence, we shall eradicate the words "the woman's" with the understanding that the judge in question is that of the vicinity of the individual whose domicile the couple chose for the wedding. By the same token, we shall efface the term "the man's," stipulating that the judge in question is from the other prospective spouse's vicinity. ${ }^{19}$

191. José Eurípides Parra Parra, C-082/99 (invalidating article 140(7) of the Civil Code which nullified marriages between "an adulterous woman and her accomplice"), available at http://www.secretariasenado.gov.co/leyes/sc082_99.htm; Miguel Ángel Garcés Villamil, C-1440/00 (invalidating articles 173 and 174 of the Civil Code, which forbade the immediate remarriage of women who were pregnant at the time of their divorce), available at http://www.secretaria senado.gov.co/leyes/sc144000.htm.

192. Yolima Milena González Bernal v. Civ. C., art. 126, Jdt. C-112/00 (Const. Ct.) (Colom.) (2000).

193. Civil Code [Civ. C.] art. 126 (1887) (Colom.).

194. González Bernal, Considerations and Justifications, XIX.

195. Civ. C. art. 131 (emphasis added) (Colom.).

196. González Bernal, Considerations and Justifications, XX.

197. Id. 
The Court expressed discomfort with its quasi-legislative role. It additionally stated that, under certain circumstances, it would not discard an unconstitutional statute.

If the unconstitutional precept's subsistence does not momentously undermine superior values and the legislature has many regulatory options, then it is advisable to grant Congress a fair period of time to address the unconstitutionality. Under these circumstances, a substitutive judgment would disproportionately undercut democratic principles. Art. 3, Constitution (Colombia) (1991). The Constitutional Court would be limiting the legislature's decision-making prerogatives. The length of the time granted lawmakers should respond to similar considerations. For instance, the more severe the impact on constitutional values is, the shorter the deadline should be. . . ${ }^{198}$

Nonetheless, the justices refused to take this approach in the case at hand. They concluded that "the Constitution [called] for a clear solution" and that "keeping the contested provision in place would ineluctably visit substantial damage upon [the society's] constitutional ideals." ${ }^{199}$

Similarly, in José Euripides Parra Parra v. Civil Code, Article 140(6), the Colombian Constitutional Court invalidated the provision in question:

A marriage shall be null and void if ... the woman has not freely acquiesced because she has been violently robbed, unless she consents when she no longer finds herself under her abductor's power. ${ }^{200}$

The justices could find "no justification for the contested norm." "201 They observed that it was "by no means clear why the law should treat men and women differently when it authorizes the validation of a marriage that follows an act of abduction or, more precisely, kidnapping." "202 They therefore held the deprivation of "kidnapped grooms of the option of remedying the insufficiency of their consent [to be] discriminatory and, hence, unconstitutional.",203

Instead of simply annulling or redrafting, the Court declared "the contested provision conditionally unconstitutional." ${ }^{204}$ It left "the challenged phrase in place with the understanding that, as required by the principle of sexual equality, either spouse may call for the annulment of the marriage or the repair of the deficiency under Article 140(6) of the Civil Code."205 The tribunal thus offered lawmakers the opportunity to rewrite the statute themselves in a non-discriminatory manner.

José Eurípides Parra Parra, who brought the preceding unconstitutionality action, has made challenging laws before the Colombian Constitutional Court a way

198. Id. Considerations and Justifications, XVIII.

199. Id.

200. Civ. C. art. 140 (Colom.).

201. José Eurípides Parra Parra v. CIV. C., art. 140(6), Jdt. C-007/01 (Const. Ct.) (Colom.) (2001), Considerations and Justifications, VI $\$ 4$.

202. Id.

203. Id. Considerations and Justifications, VI $\S 5$.

204. Id.

205. Id. 
of life. He has appeared as the named plaintiff in at least nine cases decided by that tribunal. ${ }^{206}$ The Colombian juridical order has thus demonstrated that, like many of its counterparts in the region, it grants citizens more than ample access to the courts.

Several Latin American legal systems explicitly empower writ of protection petitioners to request a separate declaration of unconstitutionality. ${ }^{207}$ In jurisdictions that grant ordinary individuals standing in unconstitutionality actions, any plaintiff may institute such a suit as part of, parallel to, or subsequent to the original proceeding. As a consequence, individuals in most Iberian American countries may now request a tribunal to set aside, with erga omnes effect, any statute that infringes upon their constitutional rights. ${ }^{208}$ They may thus overcome a basic restriction that they used to face when filing for a writ of protection. This development represents a paradigm shift, displacing in practice the notion that Latin American courts lack the power permanently to invalidate unconstitutional laws upon individual complaints.

Once again, understanding substantive entitlements south of the border demands a basic grasp of the unconstitutionality action, along with other procedural mechanisms. For instance, the repeatedly mentioned freedom of expression assumes a very peculiar form when its enforcement may take place not only through the writ of protection, but also through a universally available unconstitutionality suit. More generally, it tends to operate quite differently within a legal structure that insists on a tangible and personalized injury than within a system that imposes no such

206. See José Eurípides Parra Parra v. CIV. C., arts. 124, 125, Jdt. C-1264/00 (Const. Ct.) (Colom.) (2000) (upholding Article 125 of the Civil Code); José Eurípides Parra Parra v. CIV. C., arts. 140(5), 145, Jdt. C-533/00 (Const. Ct.) (Colom.) (2000) (upholding Art. 145 of the Civil Code); José Eurípides Parra Parra v. art. 232 del Decreto 100 de 1980, Jdt. C-083/99 (Const. Ct.) (Colom.) (1999) (upholding art. 232(2) of the Penal Code); José Euripides Parra Parra v. CIV. C., art. 140(7), Jdt. C-082/99 (Const. Ct.) (Colom.) (1999) (invalidating Article 140(7) of the Civil Code); José Eurípides Parra Parra v. CIV. C., art. 1852, Jdt. C-068/99 (Const. Ct.) (Colom.) (1999) (invalidating art. 1852 of the Civil Code, art. 3 of Law 28/32, \& art. 906(1) of the Commercial Code); José Eurípides Parra Parra v. art. 326 del Decreto 100 de 1980 Codigo Penal, Jdt. C-239/97 (Const. Ct.) (Colom.) (1997) (upholding art. 326 of the Penal Code); José Eurípides Parra Parra v. art. 362 del Decreto 100 de 1980 Codigo Penal, Jdt. C-015/97 (Const. Ct.) (Colom.) (1997) (upholding art. 362 of the Penal Code); José Eurípides Parra Parra v. CIV. C., art. 24 de la ley 190 de 1995 , Jdt. C-709/96 (Const. Ct.) (Colom.) (1996) (invalidating art. 24 of Law 190/95, which modified art. 143 of the Penal Code); José Eurípides Parra Parra v. art. 5 de la ley 190 de 1995, Jdt. C-631/96 (Const. Ct.) (Colom.) (1996) (upholding Article 5 of Law 190/95)); José Eurípides Parra Parra v. art. 263 de Codigo Penal, Jdt. C-125/96 (Const. Ct.) (Colom.) (1996) (upholding art. 263 of the Penal Code).

207. Law 7135, art. 48 (1989) (Costa Rica); Constitutional Procedures Act, Legislative Decree 2996 art. 2 (1960) (El Sal.); Judicial C. art. 2558 (1987) (Pan.); Writ of Protection Act, Law 16011 art. 12 (1988) (Uru.); Writ of Protection and Habeas Corpus Act art. 3 (1988) (Venez.). In Uruguay, however, the declaration of unconstitutionality only holds for the case at hand. URU. CONST. art. 259.

208. See ARG. Const. art. 43; Const. Ct. Act, Law 1836 (Bol.) (1998), arts. 58(II), 65; Colom. ConsT. art. 241 (1); Law 7135 (Costa Rica) (1989), art. 48; DEM. REP. CONST. art. 67(1); El SAL. ConST. art. 183; Writ of Protection, Habeas Corpus, and Constitutionality Act, Decree 1-86 (1986) (Guat.), art. 123; HoND. CONST. art. 185; NICAR. CONST. art. 187; PAN. ConST. art. 203(1); C. Civ. Pro., Law 1337 (Paraguay) (1988), art. 550; Ley Orgánica del Tribunal Supremo (Supreme Court Organic Act), art. 21. In Mexico, a super-majority of the Supreme Court or a circuit court may declare a law unconstitutional, with general effects, in a writ of protection suit if the relevant tribunal has already established the unconstitutionality in four previous consecutive decisions. Writ of Protection Act (Mex.) (1936), arts. 192-93. Article 43 of the Guatemala's Writ of Protection, Habeas Corpus, and Constitutionality Act, in turn, establishes the following. "The Constitutional Court's interpretation of constitutional and legal norms in three consecutive decisions establishes legal doctrine that other tribunals must respect." Writ of Protection, Habeas Corpus, and Constitutionality Act, Decree 1-86 art. 43 (1986) (Guat.). Finally, two -thirds of the Brazilian Supreme Court may issue a binding precedent "after reiterated prior decisions on point" whenever lower courts are divided and there is a situation of "serious legal uncertainty." BRAZ. CONST. (as amended 2004), art. $103 \S \mathrm{A}$. 
requirement. The latter arrangement, as opposed to the former, invites people to regard free speech as a public guaranty, rather than as a private prerogative. It empowers individuals, groups, and especially procurators not only to oppose discrete violations, but also to scrutinize legislative and regulatory action, as well as inaction, on the basis of the constitution's global aspirations. For instance, these parties may oppose a statute that effectively reduces diversity in or otherwise impoverishes social debate, even if the law does not directly infringe upon their own expressive liberties. The same kind of challenge could conceivably ride on individualized complaints; yet it would inevitably entail substantial procedural complications.

In stark contrast, the Constitution of the United States does not allow federal courts to pass on the constitutionality of particular statutes in the abstract, but rather requires a concrete case or controversy. ${ }^{209}$ It thus differs significantly from most of its Iberian American counterparts, which not only permit tribunals to probe into unapplied laws, but also allow any person to proceed as a plaintiff in these actions. By institutionalizing unconstitutionality suits along these lines, Latin American jurisdictions have underscored their difference with respect to the U.S. legal system, while showing their independence vis-à-vis the Continental European model.

The unconstitutionality action plays a key role in compensating for the limitations of the writ of protection, as well as in safeguarding fundamental guaranties and in policing the constitutional order. Iberian American legal systems should continue to evolve towards granting standing to the ordinary citizen in order to democratize the suit and to enhance its impact. To prevent frivolous litigation and abuse, however, they should also require a genuine interest in the dispute and impose other reasonable procedural prerequisites.

This kind of action expediently complements ordinary judicial review, by enabling a tribunal to confront unconstitutional laws head-on and before they have caused any harm upon application. The Latin American trend towards broad access represents an overall improvement, so long as courts have the capacity and the commitment to set clear bounds. Naturally, a full defense of these contentions would call for considerable elaboration. This subsection aspires simply to show the appeal of this regional development and to invite further reflection on the matter.

The Iberian American experience may actually fuel a discussion on expanding these suits in Continental Europe as well as on introducing them in the United States. Taking either of these steps, however, would require an enormous and unlikely transformation in the underlying constitutional frameworks and cultures. In any case, the contemplated sea change, along with the antecedent debate, would be immensely beneficial for these North-Atlantic societies.

\title{
C. Collective Suits
}

\author{
Nos cruzamos en noche de ventisca; \\ en las mismas posadas estuvimos, \\ ciegos dormidos y ciegos despiertos. ${ }^{210}$
}

209. See U.S. CONST. art. III \$ 2 cl. 1; Sierra Club, v. Rogers C. B. Morton, 405 U.S. 727 (1972).

210. GABRIELA MISTRAL, Dos trascordados, LAGAR II (1991). Literally: "Our paths crossed on that blustery night; we lodged at the same inns: blindly asleep and awake." 
Recently, Iberian American legal systems have been opening up to collective litigation, often along parallel lines. ${ }^{211}$ These lawsuits affect the rights of a multiplicity of individuals, who, for the most part, never actually appear in court. In fact, these absent parties are often unaware that the proceedings are even taking place.

Unlike the writ of protection, this kind of action did not originate indigenously. Instead, it emerged mostly abroad and eventually migrated to Latin America, where it ultimately underwent an idiosyncratic development. In this sense, it resembles the unconstitutionality suit; yet the latter stemmed mainly from Continental Europe, while the former derived principally from the United States.

Several Latin American jurisdictions have embraced the popular action. ${ }^{212}$ The actio popularis, a creature of Roman law, enables citizens to protect public goods through the courts. U.S. law contains similar procedures. For instance, some federal statutes authorize citizen suits, which enable personally affected plaintiffs to assert the public's interest through litigation. ${ }^{213}$ Similarly, qui tam actions empower individuals to challenge conduct that injures society in general, such as the embezzlement of state monies. ${ }^{214}$ Latin American litigants, unlike their neighbors up north, generally do not face strict standing requirements when bringing these complaints.

Brazilian law additionally allows the Public Ministry "a permanent institution, essential to the state's judicial function [and charged with defending] the legal order, the democratic system, and all inalienable social and individual interests," "215 to bring public civil actions on behalf of numerous citizens. These suits purport "to address moral and pecuniary injuries to (I) the environment; (II) consumers; (III) the urban order (IV) goods of artistic, aesthetic, historical, tourism, and landscape value; (V) other comprehensive or collective interests; [and] (VI) the economic order or the popular economy." ${ }^{, 216}$ Certain state entities and private associations may also file the complaint; yet individuals may not. ${ }^{217}$ When the legislature enacted the statute in 1985 , it drew on existing local institutions, such as the popular action, and foreign concepts, especially the U.S. class action. ${ }^{218}$ Moreover, the 1988 Constitution endorses this procedure in defining the duties of the Public Ministry. ${ }^{219}$

In U.S. class actions, the judge must make a finding of adequate representation prior to certification. ${ }^{220}$ While some scholars have argued that Brazilian courts should similarly probe into adequacy of representation, ${ }^{221}$ Brazil's public civil action

211. See, e.g., Pub. Civ. Action Act, Law 7347 (Braz.) (1985); Cd. Civ. Pro., Min. Res. 10-93-JUS (Peru) (1993), art. 82; Gen. Pro. Cd., L. 15.982 (Uru.) (1988), art. 42.

212. See Braz.Const. art. $5 \S$ LXXIII; Colom. CONST. art. 88; PAN. Const. art. $203 \S 2$; PerU CONST. art. $200 \& 5$.

213. See, e.g., Federal Election Campaign Act, 2 U.S.C. $\S 437$ (g) (1982); Clean Air Act, 42 U.S.C. $\S$ 7604 (1982); Federal Water Pollution Control Act, 33 U.S.C. $\$ 1365$ (1982); Clayton Antitrust Act, 15 U.S.C. $\$ \$ 15,26$ (1982); Title VII of the Civil Rights Act of 1964, 42 U.S.C. $\$ 2000 \mathrm{e}$ (1982).

214. See 31 U.S.C. $\$ \$ 3729-31$ (1982).

215. See BRAz. CONST. art. 127.

216. Pub. Civ. Actions Act, Law 7347 art. 1 (1985) (Braz.).

217. Id. art. 5.

218. See generally, PEdro LeZA, TeOria geral da AÇÃo CIVIL PúbliCA 161-62 (2003).

219. BRAZ. CONST. art. 129 § III.

220. FED. R. CIV. P. 23(a)(4).

221. See generally Antônio Gidi, A Representacão Adequada nas Açes Coletivas Brasileiras. Uma Proposta, 108 REV. DE PROCESSO 61 (2002); Ada Pellegrini Grinover, Ações coletivas Ibero-Americanas: 
law, like its counterpart on popular actions, calls for no such determination. ${ }^{222}$ In any case, Article 5(1) of the statute requires the Public Ministry, whenever it does not itself file the claim, to intervene and represent the public interest. ${ }^{223}$ This provision generally guarantees the presence of competent attorneys in the proceedings, but not a steadfast defense of the common good as perceived by the people affected.

Interestingly, Article 13 of the Public Civil Action Act calls for a fund into which defeated defendants must pay damages, including any moral reparation. ${ }^{224}$ It demands that the Public Ministry and community delegates take part in the administration of the monies. ${ }^{225}$ This arrangement reflects the aspiration that such compensation accrue not to individual plaintiffs as a windfall, but rather to the collectivity as a whole.

Brazilian judges have broad injunctive powers in these cases. In fact, they must grant prevailing plaintiffs an injunction unless compliance would be impossible. ${ }^{226}$ In contrast, Federal courts in the United States must refuse a request for injunctive relief whenever damages would adequately compensate the complainants. ${ }^{227}$ The Brazilian approach reveals a civil law bias in favor of specific performance. It demands considerable engagement on the part of the judiciary, which must ordinarily issue an injunction in these cases, as well as guarantee compliance.

In São Paulo Public Ministry v. Notre Dame Association, the Brazilian Supreme Court defined the contours of this procedural institution. ${ }^{228}$ The "São Paulo Public Ministry ... filed a public civil action [seeking] a preliminary injunction against respondent, Notre Dame Association for Education and Culture, a school in São Vicente, São Paulo," to adjust tuition within the "limits established by the State Education Council."229 The high tribunal unanimously agreed with the plaintiff on the merits: "Respondent undoubtedly violated the law when it authorized the tuition hike." ${ }^{.230}$ The justices further rejected "the contention that the Public Ministry [lacked] standing to defend the interests of the collectivity.",231 "In this concrete case," the Court stated, "the Ministry clearly [had] standing to bring a public civil action in order to protect collective interests in such an extremely delicate and socially significant terrain, which the state must police with utmost care."232

In his concurrence, Justice Celso de Mello agreed "that the Public Ministry [had] standing to file public civil actions to challenge the increase in monthly school fees. ${ }^{233} \mathrm{He}$ declared further that:

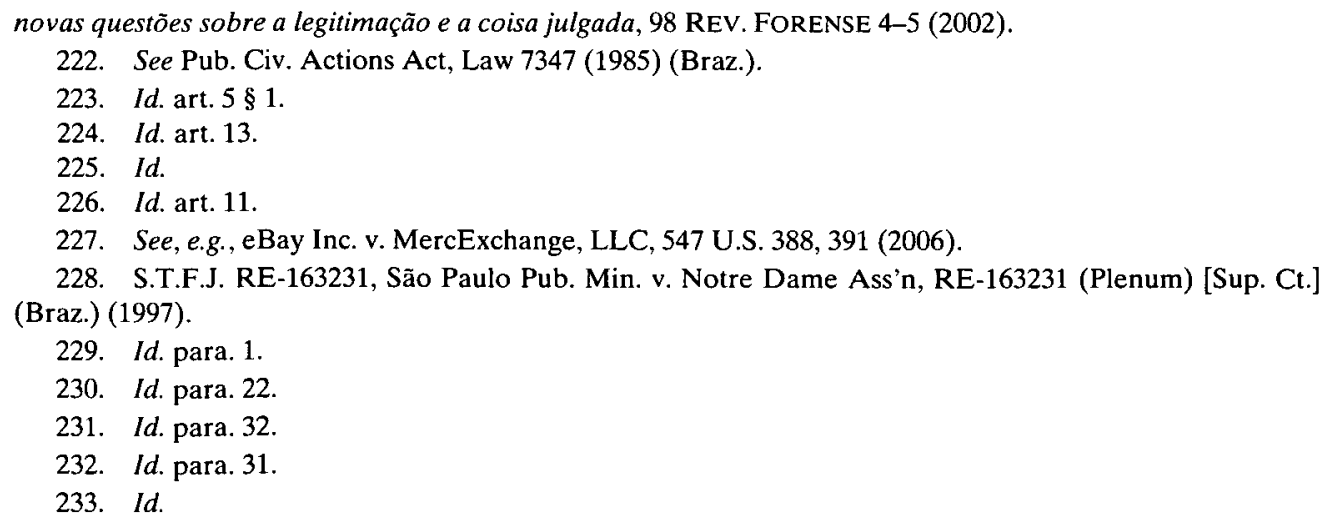


The Brazilian legal system appreciates the singularity and importance of certain social values and calls on the state to safeguard them. Accordingly, it has tended, along with its counterparts elsewhere, to collectivize procedural instruments. In particular, it has created an agile means for an effective protection in court of meta-individual interests. ${ }^{234}$

From this standpoint, de Mello concluded that the Ministry "may certainly file a complaint to defend the collective interests of private school parents and students, as well as to impede an arbitrary increase in tuition."

In public civil actions, according to the relevant statute, the "judgment shall [generally] constitute res judicata, erga omnes, within the jurisdictional limits of the issuing court." ${ }^{237}$ In Notre Dame, any one of the parents or the students could have demanded that the school comply with the injunction and started an execution proceeding in case of noncompliance. Under a complex set of res judicata rules, however, an adverse decision in these cases does not preclude subsequent individual suits. This arrangement provides an incentive for potential beneficiaries not to seek intervention in the original action, so as to be able to take a second bite at the apple in case of defeat.

Peru and Uruguay have already incorporated this kind of action into their legal order, ${ }^{238}$ while other Iberian American nations are presently considering following suit. In both the Peruvian and the Uruguayan legislative schemes, however, the final collective decision bars prior individual complaints. ${ }^{239}$ The public civil action will undoubtedly continue to diverge from the Brazilian model as it expands to other countries in the region. Nonetheless, it has the potential to follow the course that the writ of protection underwent in the twentieth century and become a universally available procedure throughout Iberian America.

Beyond popular and public civil actions, many Latin American jurisdictions have established a collective writ of protection or security. They have accordingly entitled a group to request such a writ in order to protect the rights of its membership. In Brazil, for example, political parties, unions, and organizations have a constitutional right to initiate such a suit. ${ }^{240}$ Argentina's 1994 Constitution empowers not only "individuals affected," but also the "People's Defender",24 to file these actions. It thus creates the equivalent of a U.S. class action and a Brazilian public civil action, respectively. In other words, a group of representatives, as well as an independent public organ, ${ }^{242}$ may set in motion a collective "defense of environment, competition, and consumer rights, as well as collective rights more generally."243 Of course, both Argentine and Brazilian plaintiffs must make their case on the basis of mostly documentary evidence, inasmuch as they are pursuing,

234. See São Paulo Pub. Min., (1997).

235. Id.

237. Id.; see also Lei No. 8078, Oct. 11, 1990, D.O.U. de 11.09 .1990 (Braz.).

238. C. Civ. Pro., Ministerial Resolution 10-93-JUS (1993) (Peru); General Procedural C., Law 15.982 (1988) (Uru.).

239. Id.

240. BRAZ. CONST. art. 5.

241. ARG. CONST. art. 43.

242. Id. art. 86 .

243. Id. art. 43 . 
respectively, a writ of protection and a writ of security. ${ }^{244}$ In most other Iberian American jurisdictions, however, complainants may additionally rely on other means of proof.

Not surprisingly, Latin American organizations have taken advantage of this enforcement mechanism and have forced the judiciary to detail the procedural parameters. For instance, in FEBRAC v. the President of the Republic, the Brazilian Federation of Syndicates and Associations of Maintenance and Conservation Companies (FEBRAC) sought a collective writ of security on behalf of its membership against the federal executive. ${ }^{245}$ It challenged "Law 8800 of May 27, 1994, and Provisory Measure 635 of September 27, 1994, [which established] the Program of Economic Stability, the National Monetary System, and the Institution of the Currency Real Unit of Value (RUV)." ${ }^{246}$ The plaintiff contended that the change of the official currency from cruzeiros to reais under these provisions violated the contractual rights of its constituents, ${ }^{247}$ and essentially, that the value of the underlying contracts decreased as a consequence of the conversion statute. ${ }^{248}$

The Brazilian justices dismissed the suit, accusing the complainant of illegitimately purporting to use the writ of security against a law in the abstract. They explained that this kind of challenge had to take place through an unconstitutionality action. ${ }^{249}$ Thus, the tribunal not only construed the writ of security very narrowly, but also left the petitioners with no options. The statute of limitations for an unconstitutionality complaint had probably already run and, in any case, the plaintiff did not fall within the limited category of parties that may file such a suit. Article 103 of Brazil's Constitution authorizes only the president, the legislature, state governors, the procurator general, the Brazilian Bar Association, political parties, and national unions to challenge the constitutionality of norms in the abstract. ${ }^{250}$

Prior to the settlement of the merits along these lines, the justices first had to decide whether the plaintiff had standing to appear on behalf of its membership rather than for itself. In particular, the association purported to defend its members' collective, rather than individual interests. Under the Constitution, it apparently only had to be "legally organized and in operation for at least one year," 251 in order to proceed.

The summary of the opinion in $F E B R A C$ states that: "Unions, classes, and associations have extraordinary standing to request a [collective] writ of security."252 The Court specifically held that these entities did not need "express authorization" from their membership and that "procedural substitution [took] place."253

244. See Section IV.A, supra.

245. See FEBRAC v. Presidente da República, S.T.F., Em. No. 1846-1, Relator: Min. Carlos Velloso, 18.10.1996, S.T.F.J. 185, 185 (Braz.).

246. Id. at $187-88$.

247. $I d$.

248. Id.

249. See id. at 187-94.

250. BRAZ. CONST. art. 103.

251. Id. art. 5 \& LXX.

252. FEBRAC v. Presidente da República, at 185.

253. Id. 
Accordingly, it entitled the plaintiff to represent its members' collective interests, to stand in for them procedurally, and to bind them without explicitly consulting them.

A collective security suit, therefore, differs from an ordinary organizational action, in which the decision for or against the association usually does not bind the members, unless they have previously agreed to appear as co-plaintiffs. Of course, in the latter kind of proceeding, as in the former, the judgment normally has an impact on subsequent litigation. For instance, if FEBRAC had lost in an ordinary suit instead of a collective security action, the President could have invoked this judicial determination at least as a source of persuasive reasons, though not as res judicata, against any complaint filed thereafter by particular maintenance companies. As the litigation actually unfolded, he prevailed against the organization's petition for a collective writ and therefore would have been able to preclude any subsequent individual suits.

Coincidentally, Article 5 (XXI) of Brazil's Constitution creates an associational action that similarly binds members of the plaintiff organization so long as they expressly authorize the litigation. ${ }^{254}$ In AJURIS $v$. State of Rio Grande do Sul, the Supreme Court allowed the Association of Judges of Rio Grande do Sul (AJURIS) to file such a suit on behalf of the entire membership after the group secured approval by a majority in an extraordinary meeting. ${ }^{255}$ The tribunal rejected the State's argument that the complainant, which was seeking a cost-of-living adjustment on overdue judicial salaries, could only represent those judges who had explicitly and individually consented to the action. ${ }^{256}$ As a consequence, any member of AJURIS could have subsequently demanded enforcement of the decision as res judicata.

This kind of associational action actually occupies a middle point between the collective writ of security and an ordinary suit in terms of its binding force. It differs from the former, which has an automatic preclusive effect on the plaintiff's membership, as well as from the latter, which requires individual consent in order to bind the members. As just explained, the associates must authorize the litigation filed under Article 5 (XXI) not individually, but rather collectively by majority vote, in order to have a piece of the action.

Collective suits, like protection and unconstitutionality actions, have had a peculiar development and have played a key role in the vindication of legal entitlements in Latin America. Naturally, they surfaced more recently than these two other procedural devices, are still basically under construction, and therefore have yet to take a mature form. Over the next several years, a clearer picture will likely emerge of how group litigation is finally shaping up and affecting the rights culture throughout the continent.

Collective actions also underscore the interconnection between substance and procedure. In terms of this section's recurrent example, free speech profoundly transforms itself whenever its enforcement takes place collectively. It offers new procedural possibilities and, most significantly, it expands beyond protecting personal expressions of ideas to facilitating group and even societal selfdetermination. A class suit in this area often entails much more than an aggregation of numerous ordinary actions. It frequently enables people not only to speak their minds, but also to coalesce into an organized movement. For instance, the right of

254. BRAZ. CONST. art. V § XXI.

255. AJURIS v. State of Rio Grande do Sul, AO-152 (Plenum) [Sup. Ct.] (Braz.) (1999).

256. Id. 
state employees to use their native tongue in informal settings transmutes intensely when asserted by a collectivity - such as the Aymaras in Bolivia or Latino/as in the United States-instead of an isolated individual. The interface between material and adjectival law in this context, as well as in others, certainly deserves additional attention and analysis.

Group litigation has found broad appeal in Iberian America partly as a way to make up for people's longstanding lack of access to justice and to address large-scale violations of rights. It generally enables tribunals to process mass injuries efficiently and to advance the underlying public values directly. Latin America should continue to upgrade collective suits, minding experiences abroad, as well as local conditions. The rest of the world should take notice of the remarkable developments in the region on this front.

\title{
V. INTERnATIONAL GUARANTIES: LocAl AND Global ACTION
}

\author{
Cantemos, sí, cantemos, que al cantarle al silencio, \\ a la sorda derrota y a la impar soledad, \\ venceremos la muerte, venceremos la nada, \\ y a la cumbre del tiempo nuestras almas irán. ${ }^{257}$
}

An account of rights in Latin America requires at least a rudimentary examination of how international entitlements operate in the region. Iberian American nations have joined numerous transnational conventions, ${ }^{258}$ which civil society has been invoking ever more often, both at home and abroad, in its quest for social justice. ${ }^{259}$ The symbiosis between domestic and international guaranties will continue to intensify not only in Latin America, but all over the world-even in the United States, where legal isolationism will eventually lose its appeal. Under these circumstances, one ineluctably misrepresents the rights praxis if one focuses exclusively on the national legal order.

International law has, in fact, enhanced Iberian America's substantive and procedural convergence on rights. Constitutions throughout the continent generally enunciate a strong commitment to international law, as well as to regional integration. $^{260}$ They overwhelmingly declare ratified treaties to be part of the supreme law of the land, without requiring implementing legislation. ${ }^{261}$ In fact, international law often has priority over domestic statutes. ${ }^{262}$

257. Julia de Burgos, Te llevarán, El Mar y Tú; OTros Poemas 80 (1954). Literally: "Let us sing, yes, let us sing. By singing to silence, to dull defeat, and to uneven solitude, we shall triumph over death, we shall triumph over nothingness; and our souls shall reach the summit of time."

258. Office of the United Nations High Commissioner for Human Rights, Status of Ratifications of the Principal International Human Rights Tribunals, Jun. 9, 2004, available at http://www.unhchr.ch/pdf/ report.pdf.

259. See OQUENDO, supra note 26 , at 237-39; id. at 514.

260. See Braz. CONST. art. 4; Colom. CONST. pmbl., arts. 9, 227; CuBA CONST. art. 12 § c; ECUADOR CONST. art. 4 \$ 5; El SAL. CONST. art. 89; GuAT. CONST. art. 150; Hond. CONST. art. 335; NiCAR. CONST. art. 9; PAN. CONST. pmbl; Peru Const. art. 44; URU. CONST. art. 6; VENEZ. CONST. pmbl.

261. See, e.g., COlOM. CONST. art. 93; DOM. REP. CONST. art. 3; HOND. CONST. art. 16; MeX. CONST. art. 133; NICAR. CONST. art. 5; PAN. CONST. art. 4; PARA. CONST. art. 141.

262. See, e.g., ARG. CONST. art. 93; COSTA RICA CONST. art. 7; ECUADOR CONST. art. 163; El SAL. CONST. art. 144; HOND. CONST. art. 18; PARA. CONST. art. 137. The constitutions of Guatemala and 
Many of the constitutions in the region specifically and enthusiastically embrace international human rights, from civil and political to economic, social, and cultural rights. $^{263}$ They frequently express support for transnational forums and adjudication. $^{264}$ The Bolivian and the Peruvian constitutions specifically call on the national judiciary to interpret the domestic bill of rights in accordance with international human rights law. ${ }^{265}$ The atrocities perpetrated by Latin American dictatorships in the 1970 s and 1980 s, as well as the struggle for democracy in the 1990 s, have undoubtedly fueled this transcontinental engagement in favor of human rights.

Virtually all Latin American countries have signed and ratified the 1969 American Convention on Human Rights. ${ }^{266}$ The only exceptions are Cuba and Puerto Rico, which are not full members of the sponsoring Organization of American States. Moreover, all signatory Latin American nations have accepted the compulsory jurisdiction of the Inter-American Court of Human Rights. In contrast, the United States has neither ratified the treaty nor recognized the tribunal's binding authority.

The American Convention is evolving into the functional equivalent of a constitution for the entire region. The individual provisions often operate not merely as international law, but also as part of the domestic legal order. By the same token, the Inter-American Court of Human Rights, somewhat like its European counterpart, is gradually becoming a supranational constitutional tribunal. It has taken an increasingly progressive, ${ }^{267}$ as well as assertive, ${ }^{268}$ role and has impressively developed its prestige over the last decades. The Inter-American Commission on Human Rights, which considers individual as well as state complaints, monitors human rights generally, and refers cases to the Court, ${ }^{269}$ has also contributed to the critical process of consolidating and harmonizing human rights in Latin America. ${ }^{270}$

Venezuela recognize the priority of international human rights over domestic law. GUAT. CONST. art. 46; VENEZ. CONST, art. 23.

263. See ARg. Const. art. $75 \S 22$; Braz. Const. art. $5 \S 2$; Bol. Const. art. $6 \S \mathrm{V}$; Chile Const. art. 5; COLOM. CONST. arts. 44, 93, 214; COSTA RICA CONST. art. 48; ECuADOR ConsT. arts. 18, 29, trans. art. 17; GUAT. CONST. arts. 27, 46, 106; HOND. CONST. arts. 15, 119; NICAR. CONST. arts. 46, 71, 160; PARA. CONST. arts. 143, 145; PERU CONST. trans. art. 4; VENEZ. CONST. arts. 23, 78, 339, trans. art. 4.

264. See ARG. ConST. art. $75 \S 22$; BRAZ. CONST. art. 7; Colom. Const. art. 93; Hond. ConST. art. 15; NiCAR. CONST. art. 5; PARA. CONST. art. 145; PERU CONST. art. 205; Venez. Const. art. 31.

265. See BOL. CONST. art. 6 \& V; PERU CONST. trans. art. 4.

266. AMERiCAN CONVENTION ON HUMAN Rights "PACT OF SAN JOSE, Costa RiCA" GeNERAL INFORMATION OF THE TREATY, available at http://oas.org/juridico/english/ sigs/b-32.html.

267. See, e.g., Juridical Condition and Rights of the Undocumented Migrants, Advisory Opinion OC18/03, Dispositif 9 (2003) ("[T]he State has the obligation to respect and guarantee the labor human rights of all workers, irrespective of their status as nationals or aliens, and not to tolerate situations of discrimination that are harmful to the latter in the employment relationships established.").

268. See, e.g., Baena Ricardo Case, (270 workers v. Panama) Competence, Series C; No. 104, Dispositif 2 (2003) ("[I]n the exercise of its competence to monitor compliance with its decisions, the InterAmerican Court of Human Rights is authorized to request the responsible States to submit reports on the steps they have taken to implement the measures of reparation ordered by the Court, to assess the said reports, and to issue instructions and orders on compliance with its judgments.").

269. Organization of American States, American Convention on Human Rights, arts. 41, 61(I), Nov. 22, 1969, O.A.S.T.S. No. 36, 1144 U.N.T.S. 123.

270. See, e.g., María Eugenia Morales Aceña de Sierra v. Guatemala, Case 11.625, Inter-Am. C.H.R. Report No. 4/01, available at http://www.cidh.oas.org/annualrep/2000eng/ChapterIII/Merits/ Guatemala11.625.htm; Inter-Am. C.H.R., Report on the Human Rights Situation in Venezuela, OEA/Ser.L/V/II.118, doc. 4 rev. 2, paras. 533-35 (2003) (strongly condemning the 2002 coup and 
This article will not provide a full account of these phenomena; yet it will point to the way in which they bear upon the struggle for fundamental entitlements south of the border.

As already noted, the Inter-American system has played a critical role in the campaign to force Latin American governments to take the HIV/AIDS crisis seriously and in the development of the writ of protection. It has similarly supported the battle against codified sexism in the region. In the previously referenced Colombian cases, the plaintiffs invoked international treaties, even though the Constitutional Court ultimately decided on the basis of the domestic law. ${ }^{271}$ In other Iberian American countries, international law has featured more prominently in this struggle.

In Guatemala, for instance, the Human Rights Procurator and the Center for Justice and International Law challenged Articles 109, 110, 113, 114, 115, 131, 133, 255, and 317 of the Civil Code, which discriminate against women on matters of marriage and childcare. ${ }^{272}$ In 1993, the Guatemalan Constitutional Court dismissed the action. ${ }^{273}$ Thereafter, María Eugenia Morales Aceña de Sierra, who had litigated the case as Deputy Procurator for Human Rights, and the Center for Justice and International Law petitioned the Inter-American Commission on Human Rights. ${ }^{274}$

In 1998, the Commission issued an initial report "finding that the State of Guatemala was responsible for having violated the rights of María Eugenia Morales [Aceña] de Sierra to equal protection, respect for family life, and respect for private life established in Articles 24, 17 and 11 of the American Convention on Human Rights." 275 It also held "that the conduct at issue also constituted violations of the obligations set forth in the Convention on the Elimination of All Forms of Discrimination against Women, most specifically, in Articles 15 and 16."276 In response, "the State informed the Commission that the Congress had ... approved Decree Number 80-98, enacting reforms to ... Articles 109, 110, 115, 131 and 255, and the derogation of Articles 114 and 133 [of the Civil Code]. ${ }^{277}$

Upon acknowledging that the state had "addressed seven of the nine provisions challenged by the petitioner, the Commission [requested] information as to any measures taken with respect to Articles 113 and 317, which were not addressed in Decree 80-98." ${ }^{278}$ State officials eventually reported the derogation of Article 113. ${ }^{279}$

In its 2001 decision, the Commission recognized the authorities' response to its 1998 decision as "a significant advance in the protection of the fundamental rights of the victim and of women in Guatemala" and as substantial compliance with its recommendations and with the state's obligations under the American Convention. ${ }^{280}$

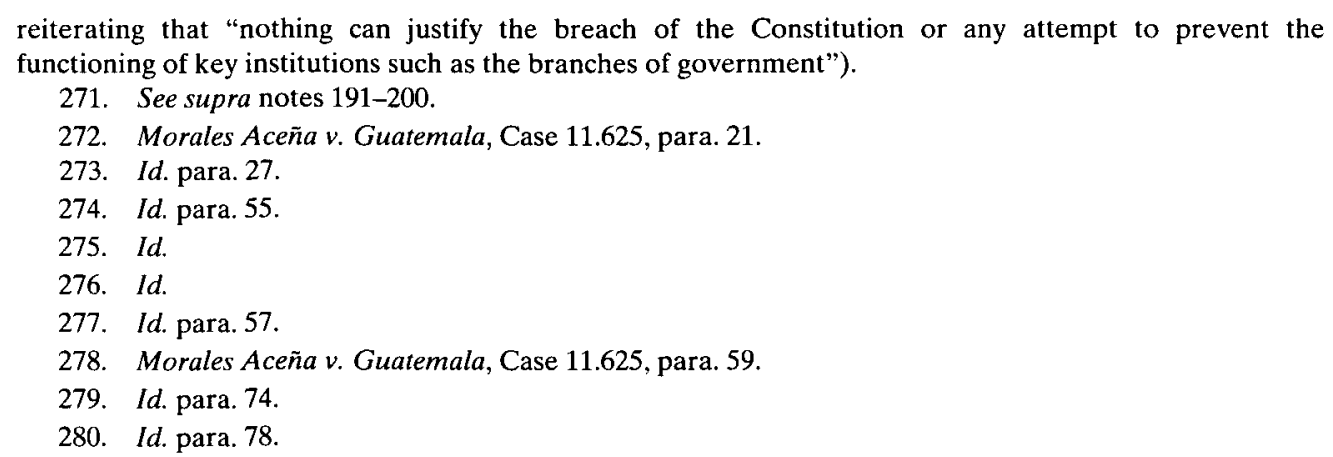


Nonetheless, the Commissioners underscored the absence of complete compliance. They explained the insufficiency of the amendments to Article 110 in the following terms:

The original heading and first paragraph of Article 110, which remain in force, refer to the duty of the husband to protect and assist his wife within the marriage, a duty that, in and of itself, is consistent with the nature of the marital relationship, [but that also reflects] an imbalance, [inasmuch as] the law does not impose the same duty on [the wife] with regard to her husband. $^{281}$

The decision makers also complained about the failure to alter Article 317, which lists women as one of the categories of people that "may be excused from exercising custody and guardianship" of children. ${ }^{282}$

Essentially, the terms of Article 317 identify categories of persons who may be excused from custody or guardianship due to limitations, for example, economic or health reasons. It is not evident, nor has the State explained what limitation justifies including "women" in these categories. According to Article 17 of the American Convention, and as expressly stipulated in Article 16 of the Convention on the Elimination of All Forms of Discrimination against Women, States Parties must guarantee equal rights and duties with regard to exercising custody and other forms of guardianship of children. ${ }^{283}$

The Commissioners summarized their objections thus:

In this sense, both Article 317 and the title and first paragraph of Article 110 suggest, expressly or implicitly, that women are characterized by inherent weaknesses that limit their capacity as compared to men. This affects María Eugenia Morales [Aceña] de Sierra in her right to equal protection of the law, in accordance with Article 24 of the American Convention, and to respect for her human dignity, pursuant to Article 11 of that Convention. Additionally, as stated in paragraph 44 above, these norms apply stereotyped notions about gender roles, thereby perpetuating de facto discrimination against women in the family sphere. Further, with regard to the question of compliance with the recommendations, the State has provided no measures of reparation to the victim in response to the findings and recommendations of the Commission. ${ }^{284}$

281. Id. para. 79.

282. Article 317 of the Civil Code establishes: "(Exemption). The following may be excused from exercising custody and guardianship: 1) Those already exercising another custody or guardianship; 2) Persons over sixty years of age; 3 ) Those who have three or more children under their parental authority; 4) Women; 5) Persons of low-income for whom this responsibility would threaten their means of subsistence; 6) Persons prevented from exercising this responsibility due to chronic illness; and 7) Those who have to be absent from the country for over one year." Id. para. 28; Accord Código Civil de Guatemala, art. 317.

283. See generally Morales Aceña v. Guatemala, Case 11.625.

284. Id. para. 81 . 
The opinion, accordingly, takes a first step towards articulating an account of the subordination of women. As part of this effort, it calls attention to the sociological link between unequal protection of the law and violence against women ${ }^{285}$ and states that the Civil Code not only oppresses women, but also impedes men from entirely developing "their roles within the marriage and family." 286 In any case, the Commission has retained jurisdiction and has committed to staying on the case "until the State has fully complied."287

Remarkably, the Commission brought about the amendment of eight out of the nine challenged provisions and maintained its pressure to produce further changes in the Civil Code. Of course, it did not act in a vacuum, but rather in the context of an extremely proactive women's movement, which fiercely lobbied the Guatemalan legislature.

The decision will have considerable impact throughout Latin America. The Commission has jurisdiction over all countries in the Organization of American States, regards its precedents as binding, and tends to act consistently in the enforcement of human rights. Moreover, national public institutions throughout Iberian America have not only prudential, but also constitutional reasons to respect this holding as an official interpretation of a signed and ratified treaty-the American Convention.

In fact, Latin American courts regularly follow the case law of the Commission and especially of the Inter-American Court. In Miguel Ángel Ekmekdjián v. Gerardo Sófovich (Ekmekdjián II), for instance, the Argentine Supreme Court declared that the right of reply derived from the American Convention, Article 14 and "therefore [constituted] the supreme law of the land, in accordance with Article 31 of the National Constitution." 288 It recognized, further, an obligation to heed the Inter-American Court's case law: "The interpretation of the treaty must also follow the precedents of the Inter-American Court of Human Rights, whose role is to interpret the American Convention on Human Rights." 289

The Argentine justices rejected the contention that the enforceability of the guaranty in question depended on whether the government had regulated the details. They relied on an opinion of the Inter-American Court that stated: "The fact that the States Parties may fix the manner in which the right of reply or correction is to be exercised does not impair the enforceability, on the international plane, of the obligations they have assumed under Article 1(1)."290 Argentina's highest tribunal concluded that the needed regulation could stem from the legislature or the judiciary and, quoting once again the words of the Inter-American

285. Id. para. 52 .

286. Id. para. 44.

287. Id. para. 86 .

288. Corte Suprema de Justicia de la Nación [CSJN], 7/7/1992, "Ekmekdjián v. Sófovich / amparo," La Ley [L.L.] (1992-C-546) (Arg.); Const. Arg. (1994), art. 31 ("This Constitution, national laws enacted pursuant to it by the Congress, and treaties entered into with foreign powers are the supreme law of the land.").

289. "Ekmekdjián v. Sófovich / amparo," La Ley [L.L.] (1992-C-547-48) (Arg.).

290. Id. (quoting Corte Suprema de Justicia de la Nación [CSJN], 7/1986, "Exigibilidad del derecho de rectificación o respuesta / opinión consultiva," La Ley [L.L.] (1986-A-13); Organization of American States, American Convention on Human Rights, arts. 14.1, 1.1, 2, Nov. 22, 1969, O.A.S.T.S. No. 36 , 1144 U.N.T.S. 123). 
Court, noted "that 'any State Party that does not already ensure the free and full exercise of the right of reply or correction is under an obligation to bring about that result, be it by legislation or whatever other measures may be necessary under its domestic legal system.",291

In fact, the Argentine Supreme Court revoked its own precedent, Miguel Ángel Ekmekdjián v. Bernardo Neustadt et al. (Ekmekdjian $n$ ), on the basis of this InterAmerican decision. Ekmekdjián I had previously held that "the right of response or reply established in Article 14(1) of the American Convention on Human Rights [had] not yet been the object of legal regulation so as to become positive domestic law."292 Ekmekdjian II not only rejected this analysis, but actually proceeded to regulate the entitlement in question.

In sum, an account of the rights culture in Latin America and beyond must come to terms with international, as well as procedural, entitlements. Domestic legal systems have internalized transnational norms, while international institutions play an ever more prominent role throughout the continent. To focus exclusively on substantive national rights is to present a partial and distorted picture.

Once again, the free speech example illustrates this point. As the Ekmekdjian controversy shows, freedom of expression in Argentina and elsewhere in the region transcends strictly national law. It also derives from international norms and precedents, and, accordingly, incorporates entitlements that have yet to attain explicit domestic recognition, such as the right of reply. Along similar lines, the Dominican Supreme Court's decision in Avon, which the previous section discussed, demonstrates the incompleteness of any analysis of due process that concentrates solely on Dominican legal precepts to the exclusion of their international counterparts.

This internationalization of domestic law, along with the concomitant domestication of international law, constitutes a response not only to the deficiencies of local legal systems, but also to the outrages of the dictatorial regimes of 1970 s and 1980s. This development is commendable inasmuch as it means that victims may invoke transnational human rights and interpretations at home, as well as appeal to a whole new set of institutions when the national courts fail. By participating in this process, Latin American countries coincidentally advance in their quest for integration.

\section{Dysfunctions in the Rights Culture: A Walk on the Wild SIDE ${ }^{293}$}

Toda coerência é, no mínimo, suspeita. ${ }^{294}$

Alongside the streaks of light, portentous shadows run through this picture. In particular, the implementation of these guaranties has given rise to numerous difficulties. Despite many prodigious victories, political and legal institutions have

291. Id.

292. "Ekmekdjián v. Sófovich / amparo," La Ley [L.L.] (1992-C-547-48) (Arg.), para. 26.

293. See generally NELSON AlgREN, A WALK ON THE WILD SidE (1956).

294. Nelson Rodrigues, Flor de Obsessão, in COMPHANIA DAS LETRAS (Ruy Castro ed., 1997), available at http:/www.releituras.com/nelsonr_flor.asp (last visited Apr. 7, 2008). Translation: “All coherence is, at the very least, suspect." 
all too often failed to understand second- and third-generation rights as requiring the government to commit to specific, long-term programs, rather than merely posturing. Moreover, time and again, the innovative procedural mechanisms operate in an inefficient manner. For instance, many jurisdictions require endless adjudication of the same issue from one protection petition to the next, impose excessive restrictions on unconstitutionality actions, and do not allow individuals to bring collective suits. Finally, the main Inter-American organs responsible for human rights have received scant support from the Organization of American States in enforcing their determinations.

Beyond these challenges, which demand enormous changes in legal structure and culture, Iberian American societies have faced a more basic challenge. Now and again, they have fallen prey to widespread lawlessness (non-droit). They have frequently tolerated a yawning gap between legal norm and legal reality - that is, between the law on the books and the law in practice. In fact, some scholars have identified this systematic violation of the rule of law as characteristic of Latin American law. ${ }^{295}$

This unfortunate phenomenon has become part of the local folklore and has fueled numerous jokes over the years, such as the following:

A not particularly pious individual dies and, thereupon, goes straight to hell. The devil is in a good mood and allows him to choose between a Puerto Rican and a German inferno. The man opts for the latter, hoping for first-world infrastructure and organization. When he finally arrives at his destination, the on-site manager informs him that he will have to work almost uninterruptedly and that, every hour on the hour, a truck will drive by, loaded with manure, which several workers will shovel all over him, as well as over other lost souls, while whipping anyone they see lazing off. Shortly thereafter, he confirms that everything runs exactly as described by the boss. After a few eternities of this horrible routine, he becomes curious and requests permission to visit the Puerto Rican underworld for a day. Lucifer accedes and the fellow begins his tour. He encounters masses of people singing, dancing, drinking, partying, hugging, relaxing, and having a good time. After several hours, he approaches a passer-by and asks her whether he is actually in hell. She reassures him: "Yes, sir, Puerto Rican hell." He then explains that he comes from German hell and details what the rules are like there. "Here the rules are the same," the woman responds, "yet sometimes the truck is out of service, sometimes the dung has run out, sometimes the employees are on strike, and ultimately nothing ever happens."

Descriptions of the legality deficit in Latin America often sound as extreme as this story. Some theorists and lawyers have even made a career out of arguing that legal norms invariably command no respect whatsoever and that violators can always escape sanctions rather cheaply. In fact, the extent to which people and institutions honor the rule of law varies enormously among and within the various countries in the region. ${ }^{296}$ Moreover, even in the most anarchistic contexts, individuals

295. See Jorge Witker Velásquez, Derecho, desarrollo y formación jurídica, 2 ANUARIO JURÍDICO, INSTITUTO DE INVESTIGACIONES JURÍDICAS 295, 299-300 (1975); Ernesto Garzón Valdés, Eine kritische Analyse der Funktionen des Rechts in Lateinamerika, 23 IBEROAMERIKANISCHES ARCHIV. ZEITSCHRIFT Für SOZIALWISSENSCHAFTEN UND GESCHICHTE 323-24 (1997).

296. Rogelio Pérez Perdomo similarly qualifies the extent of the mismatch between legal practices and principles. See generally Rogelio Pérez Perdomo, Notes for a Social History of Latin American Law: 
occasionally confront most unpleasant surprises when they try to purchase immunity for their legal outrages.

While presently not as pervasive or severe as in the past, the rule of law problem persists and intermittently threatens the vindication of rights, as well as the specific accomplishments analyzed in this article. This section therefore explores the issue, though not by pointing at particular instances or by suggesting how the legal system might respond. This piece has already examined cases in which political or juridical institutions have failed to do justice to constitutionally or statutorily guaranteed entitlements and has repeatedly shown how individuals, nongovernmental organizations, autonomous state entities such as the public ministry, domestic courts, and international adjudicators might jointly and separately compel compliance. The discussion now acknowledges that these responses will not by themselves solve the predicament in question and, accordingly, looks for underlying causes and broader solutions.

This Part differs from the preceding ones not only in that it focuses on the vices rather than the virtues of Latin American rights praxis, but also in that it entertains matters of law and politics at a rather general and theoretical level. It does so in order to uncover the roots of the difficulties under consideration and to search for more comprehensive and permanent answers. Ineluctably, the advanced reflections only launch the debate and in no way purport to settle it.

Whenever a community systematically disregards the law, it usually faces a situation in which legal norms themselves lack legitimacy. ${ }^{297}$ This deficiency at times responds to the absence of a well-functioning democracy. When dictatorships pervaded in Iberian America, for instance, legal precepts expressed heteronomy and therefore intrinsically inspired minimal respect within the population, as well as within the state. ${ }^{298}$

Of course, democratic institutions do not necessarily guarantee the rule of law either. ${ }^{299}$ Once again, Latin America provides a case in point. Since the late 1980s, the region has generally embraced democracy. The illegality crisis may have abated somewhat as a consequence; yet it has by no means completely disappeared. The explanation for the persistence of the problem lies partly in the fact that most Latin American countries have made only a formal, not a substantive, commitment to democracy. They have merely gone through the motions and have not allowed real autonomy to flourish.

An overly instrumental understanding of politics has frequently prevailed. Political actors have, accordingly, played the democracy game strategically, instead of participating in genuine democratic interaction. They have formed tactical alliances and, when victorious, they have divided up the spoils of war with their allies. They have undertaken grand propagandistic drives, often devoid of real content, to capture votes, both in the electorate and in the legislature. In the end, the societies in question, like many of their counterparts across the planet, have

The Relationship Between Legal Practices and Principles, 52 REV. Colegio de ABogados P.R. 1, 1-12 (1991).

297. See generally JÜRgEN HABERMAS, LEGITIMATION CRISIS 2 (1975).

298. See Ángel R. OQuendo, Democracia y Pluralismo 119-45 (2004).

299. Jürgen Habermas elucidates the relationship between democracy and the rule of law. JüRGEN HABERMAS, DIE EINBEZIEHUNG DES ANDEREN: STUDIEN ZUR POLITISCHEN THEORIE 293-305 (1996). 
experienced not a real development, but instead a trivialization of the democratic process.

Consequently, private citizens have had a rather passive role. They have participated only intermittently, such as when an election or referendum has taken place. At most other times, they have hibernated politically. Evidently, politicians have spent enormous amounts of energy and money to obtain popular support during the electoral season. Nonetheless, they have focused more on manipulating than on engaging the electorate.

Under these circumstances, many people both within and without the establishment have maintained their pre-democratic skepticism and sometimes even their cynicism vis-à-vis the law that their political institutions generate. As a result, constitutional as well as statutory rights have not fully delivered on their promise. They often shine in the texts of law, but fade in the real world. The wonderful accomplishments previously referenced remain somewhat exceptional.

In order to escape this quagmire, Latin America-along with much of the rest of the globe-must renew and radicalize its commitment to democracy. Specifically, it must overhaul the instrumental understanding of politics in favor of a more reflexive one. ${ }^{300}$ In other words, individuals must visualize their political activity as an end in itself. They must approach democratic engagement as an ongoing process through which the community exists as such and gives itself the law by which it lives. ${ }^{301}$ This collective effort towards autonomy may take a multiplicity of forms: dialogue, argument, self-definition, deliberation, negotiation, emotional outburst, bonding, inner rivalry, as well as gamesmanship. ${ }^{302}$ Thus, politics should transcend mere strategizing, and political precepts should map out not an obstacle course, but an intrinsically meaningful existential space, within which the community becomes its own master. ${ }^{303}$

From this vantage point, the political world would encompass all citizens, not just politicians. Civil society would profile prominently. The citizenry would no longer be simply a source of electoral reinforcement, but would become, through its civic organizations, an immanent presence in politics. It would bring forth initiatives, ideas, and criticisms. It might, depending on the issue, work alongside, against, or independently of its representatives. It would, in any case, be an integral part of the communal self-legislation tour de force.

300. Jürgen Habermas proposes a reflexive approach to a morality based on intersubjective consensus. JÜRgEN HABERMAS, MORALBEWUBTSEIN UND KOMMUNIKATIVES HANDELN 177 (1983). He also calls for reflexivity in the construction of the democratic principle, legal norms, and political rights. JÜRGEN HABERMAS, FAKTIZITÄT UND GELTUNG: BEITRÄGE ZUR DISKURSTHEORIE DES RECHTS UND DES DEMOKRATISCHEN RECHTSSTAATS 142-43, 647 (1992).

301. This approach resembles what H.L.A. Hart denominates the "internal point of view." HERBERT LIONEL ADOLPHUS HART, THE CONCEPT OF LAW 199 (1984). Ernesto Garzón Valdés maintains that to confront political corruption head on, it is necessary to "make sure that decision makers adopt an internal point of view with respect to the basic rules of the relevant normative system." Ernesto Garzón Valdés, Acerca del concepto de la corrupcion 10 (unpublished manuscript, on file with author). He notes that taking this internal point of view implies moving to a deeper understanding of democracy. Id.

302. See Ángel R. Oquendo, Deliberative Democracy in Habermas and Nino, 22 OXFORD J. LEGAL STUD. 189 (2002).

303. Iris Marion Young similarly strives to sketch an alternative to formal and traditional approaches to democracy and politics. See generally IRIS MARION YOUNG, JustiCE AND ThE POLITICS OF DIFFERENCE (1990); IRIS MARION YOUNG, INCLUSION AND DEMOCRACY (2000). 
Such a radical transformation would require numerous complex and long-term measures. It would call for a reduction in the influence of money through limited and mostly governmental funding of campaigns and through restrictions on the extent to which the winners could reward their supporters with employment, contracts, or access. The public sphere would also have to become stronger through, for example, government subsidies for private groups and initiatives. In addition, education would have to improve in order to empower all individuals not only politically, but also socially. Finally, international institutions would have to emerge to monitor both the integrity of vote tallying and the fundamental fairness of the antecedent deliberation.

The legitimacy of the law rides not only on the extent to which a community fulfills its democratic aspirations. It also hinges on other ideals, such as solidarity, personal liberty, and the rule of law itself. Each of these categories has a corresponding guiding principle, antithesis, and conception of the state. In the name of solidarity, citizens embrace equality as a norm and seek to reduce inequality through a social state. ${ }^{304}$ On behalf of personal liberty, they adhere to the precepts of liberalism and forestall totalitarianism by establishing liberal government. ${ }^{305}$ In pursuit of the rule of law, they uphold legality and minimize arbitrariness by means of a legalist regime. ${ }^{306}$ Figure 1 schematizes all of these dimensions of the notion of legitimacy.

Figure 1. Dimensions of Legitimacy

\begin{tabular}{|l|l|l|l|}
\hline \multicolumn{1}{|c|}{ State Conception } & Action Principle & \multicolumn{1}{c|}{ Antithesis } & Overarching Ideal \\
\hline 1. Democratic State & Autonomy & Heteronomy & Democracy \\
\hline 2. Social State & Equality & Inequity & Solidarity \\
\hline 3. Liberal State & Liberalism & Totalitarianism & Personal Freedom \\
\hline 4. Legalist State & Legality & Lawlessness & Rule of Law \\
\hline
\end{tabular}

Because an elaboration of the details of this complex conceptual scheme would outrun the limits of the present work, I will simply make two observations. First, the claim that the principle of legitimacy bears on that of legality and that the latter affects the former is not circular. It simply expresses the idea that the allegiance to the laws in place usually depends on how legitimate they are, which, in turn, rides on the prevalence of the rule of law, as well as on other factors, such as the solidity of democracy. For instance, people will tend to comply with an income redistribution statute insofar as social or legal mechanisms exist that generally guarantee compliance and to the extent that the enactment took place democratically.

Second, Iberian American societies have most conspicuously failed to commit to true solidarity. They have distributed opportunities, wealth, and power extremely unequally and have fallen far short of establishing a social state. The bare-bones welfare system that emerged throughout the twentieth century collapsed in the neoliberal euphoria of the 1990s. The current turn to the left throughout the region stems in part from (and constitutes a reaction to) this development. The leftist

304. Richard Rorty pursues a non-essentialist understanding of the idea of solidarity. RICHARD RORTY, CONTINGENCY, IRONY, AND SOLIDARITY 189-98 (1989).

305. This notion of liberalism is narrower than the traditional one. $C f$. RONALD DWORKIN, A MATTER OF PRINCIPLE 181-204 (1985).

306. Joseph Raz warns against exaggerating the importance of the notion of the rule of law, especially $v i s$-à-vis social values. JOSEPH RAZ, THE AUTHORITY OF LAW 210-29 (1979). 
governments in Argentina, Bolivia, Brazil, Chile, Nicaragua, Peru, Uruguay, and Venezuela now face the challenge of making equality a collective priority, while upholding autonomy, liberalism, and legality. They must, in other words, simultaneously advance solidarity, democracy, personal freedoms, and the rule of law as well as erect a social, democratic, liberal, and legalistic state. The underlying communities must, accordingly, radically reduce inequality without degenerating towards heteronomy, totalitarianism, and anomie. I will certainly not risk a prediction on the prospects of Latin America embarking on and succeeding at such a mighty undertaking.

Insofar as Iberian American nations evolve towards authentic democracy, solidarity, personal freedom, and the rule of law along these lines, they will increase the respectability of enacted laws and deepen their commitment to the principle of legality. While they will clearly never attain utopia, they might at least end up taking legal entitlements more seriously and increasing the likelihood of triumphs such as those discussed earlier. While the underlying ideal remains immensely remote, however, the struggle for rights will continue to unfold arduously, uncertainly, nonlinearly, and disappointingly.

Even if Latin Americans make reasonable progress in this endeavor and consolidate their rights culture, they will not automatically enter the realm of ends. In fact, the full realization of social justice requires more than the vindication of rights. It also demands profound alterations in the distribution of respect, influence, and privilege, and even in the mode of production of goods and services. Such a radical transformation will take concerted and broad-based action in the world of politics, as well as in civil society. The enforcement of rights within legal and political institutions, or even outside the state, may contribute to this effort, but by no means will it play the whole part.

For example, indigent HIV/AIDS patients should undoubtedly fight for their constitutional guaranties and thus secure not only adequate care and medication for themselves, but also a comprehensive treatment and prevention plan for the entire citizenry. Nonetheless, they should additionally seek to shake up popular attitudes towards homosexuals, the disease, and the poor. More fundamentally, they should press for change in societal and economic life so as to attenuate marginalization and reduce their own vulnerability in the face of almost any kind of adversity. As their cause broadens, it will gradually become that of all victims of exclusion and that of the community as a whole.

These observations underscore the fact that battling exclusively for legal entitlements leads nowhere. The battle must be part of a larger utopian campaign to make the norms of collective interaction more legitimate and to institute a truly democratic, social, liberal, and legalist state or, actually, society. Realizing the insufficiency of rights may be the true "beginning of wisdom.",307

Some commentators have criticized rights not only as insufficient, but also as detrimental to the quest for social justice. The gist of this objection is that when social outcasts claim their rights, they recognize and strengthen the very state or international framework that makes their subjugation possible. They may receive some benefits, but they end up perpetuating their condition. This criticism, which

307. "The fear of the Lord is the beginning of wisdom: and the knowledge of the holy is understanding." Proverbs 9:10 (King James). 
takes infinitely different forms and levels of complexity, goes back at least to Karl Marx. $^{308}$ It has had many relatively recent reincarnations ${ }^{309}$ and deserves careful examination, far beyond the quick comments that it will draw from this concluding section.

The remonstration in question culminates the critique of rights fetishism: People need genuine emancipation, yet they instead pursue an assortment of entitlements. They fail to appreciate that the latter essentially diverges from, often fails to deliver, and sometimes even hinders the former. Enlightenment and liberation will come about only by overcoming the mystifying obsession with rights.

This line of reasoning has considerable appeal, particularly in certain contexts. For instance, one might contend that the adoption of the 1991 Constitution, the institution of the Constitutional Court, and the subsequent rights revolution in Colombia have ultimately worked to the advantage of the elite and to the disadvantage of the underclass. The traditionally dispossessed population has secured many entitlements, but in the process, the upper crust has solidified its position of domination and the space for challenging basic or systemic inequalities seems to have diminished. Progressive movements now tend to work within - rather than against - the system. Even reactionary groups, which viscerally oppose any wealth redistribution or relinquishment of their privileges, generally accept - out of self-interest - the constitutional developments of the last fifteen years.

While this concrete situation admits very different interpretations, it does seem to reflect, at least in part, the underlying predicament. Nevertheless, it invites the critique to transcend sheer negativity and become dialectical by superseding (in the sense of aufheben) the notion of rights. Accordingly, critics should overcome as well as preserve that concept; they should transform it without completely eliminating it. They should call for the implementation of entitlements through a larger, revolutionary effort on behalf of social justice. This new critical approach would view rights more expansively-invoking them both within and against the state apparatus or the international order. - and also, more tentatively-discarding them when they become counterproductive. It would thus arrive, perhaps, at wisdom itself.

\section{CODA AND FLASHBACK}

que todo el mundo sepa

que el sur también existe. ${ }^{310}$

308. See Karl MarX \& Friedrich Engels, Zur Judenfrage (1843); Kritik des GothaER Programms (1875) WERKE (Band 1 \& 19) (Dietz Verlag 1981).

309. See, e.g., Peter Gabel, The Phenomenology Of Rights-Consciousness And The Pact Of The Withdrawn Selves, 62 TEX. L. REV. 1563, 1576-77 (1984), David Kennedy, The International Human Rights Movement: Part of the Problem?, 15 HARV. HuM. RTS. J. 101, 112-14 (2002); Richard Rorty, What's Wrong with "Rights"?, HARPER'S MAG., June 1996, at 15-18; Richard Rorty, Human Rights, Rationality and Sentimentality, in ON HUMAN RigHTS: THE 1993 OXFORD AMNESTY LECTURES, 112-34 (Susan Hurley \& Stephen Shute eds., 1993).

310. MARio BenedetTI, El sur también existe, in PREguntas AL AZAR (1986). "Let the whole world know that the South also exists." 
After such a long journey, this section simply takes stock. It describes the argumentative path and quickly assesses the conclusions. It ends with some speculation on the work ahead.

Following a detailed introduction, Part II defined the term "Latin America" for purposes of the discussion and restricted the scope of attention to Iberian America. Part III launched the argumentation itself. It specifically illustrated how Latin American legal systems have not only unanimously affirmed programmatic rights, but also witnessed extremely vigorous judicial enforcement of these entitlements. Thereafter, Part IV demonstrated how Iberian American jurisdictions have converged on a most creative set of procedural mechanisms-such as the writ of protection or security, unconstitutional actions, and collective suits-for the vindication of fundamental guaranties. Part $\mathrm{V}$ showed how the countries in the region have simultaneously and similarly embraced the internationalization of individual and collective liberties.

Part VI radically shifted both the content of the discussion and the level of the analysis. It specifically explored potential threats to, as well as the limitations of, the realization of rights in Latin America from a general and rather theoretical standpoint. The instability of the rule of law could undermine the referenced accomplishments. Consequently, Iberian American nations must, over the long term, augment the legitimacy of their laws by renewing their commitment to democracy, personal freedom, the rule of law itself, and (especially) solidarity. Even if they succeed in this complicated and unlikely venture to secure the enforceability of entitlements, they will have to take other steps in addition to, as well as in substitution of, the pursuit of rights in order to attain social justice.

In the process of telling this story, the article has explicitly made crucial and universally relevant conceptual moves. It has proceeded both descriptively and normatively, taking legal reality in its present form and imagining a possible transformation on the basis of a series of current positive trends. The piece has also approached rights in a comprehensive, rather than compartmentalized, manner. Accordingly, it has construed positive, procedural, and international entitlements in conjunction with their negative, substantive, and domestic counterparts, cautioning that deliberation on the latter subset, decoupled from the former, breeds distortion and confusion. Finally, it has contemplated not only the functions, but also the malfunctions and dysfunctions of law, with an eye to deciphering the perils that legal systems and, particularly, reform proposals face.

This project invites further research on the extent, the mechanics, and the diversity of the developments under consideration. It also seeks to provoke further reflection on broader menaces to the vindication of rights, as well as to the struggle against subordination. Finally, the paper starts a theoretical debate on reconstructive approaches to law, on the advantages of interpreting entitlements comprehensively, and on the need to consider "the good, the bad, and the ugly" when thinking about rights.

Latin Americans have made remarkable progress of late in realizing the guaranties that their constitutions establish. They must continue and intensify this effort by radically transforming themselves and their societies. Only then will they 
"have, for once and for all, a second chance on the face of the earth." 311 1982), available at http://nobelprize.org/literature/laureates/1982/marquez-lecture.html. 